Article

\title{
Paclobutrazol Application Favors Yield Improvement of Maize Under Semiarid Regions by Delaying Leaf Senescence and Regulating Photosynthetic Capacity and Antioxidant System During Grain-Filling Stage
}

\author{
Muhammad Kamran 1,2,3,4,+, Shakeel Ahmad 1,2, ${ }^{+}$, Irshad Ahmad 1,2, Izhar Hussain ${ }^{5}$, \\ Xiangping Meng ${ }^{1,2}$, Xudong Zhang ${ }^{1,2}$, Tehseen Javed ${ }^{6}\left(\mathbb{D}\right.$, Misbah Ullah ${ }^{7}$, Ruixia Ding ${ }^{1,2}$, \\ Peizhi $\mathrm{Xu}^{3,4}$, Wenjie Gu ${ }^{3,4, *}$ and Qingfang Han 1,2,* \\ 1 Key Laboratory of Crop Physio-ecology and Tillage Science in Northwestern Loess Plateau, Ministry of \\ Agriculture, College of Agronomy, Northwest A\&F University, Yangling 712100, China; \\ drkamran2017@nwsuaf.edu.cn (M.K.), shakeel@nwsuaf.edu.cn (S.A.), irshadahmadagr@gmail.com (I.A.), \\ xiangpingm@nwsuaf.edu.cn (X.M.), hekedazxd@163.com (X.Z.), ruixiading81@163.com (R.D.) \\ 2 Key Laboratory of Agricultural Soil and Water Engineering in Arid and Semiarid Areas, Ministry of \\ Education, Institute of Water Saving Agriculture in Arid Areas of China, Northwest A\&F University, \\ Yangling 712100, China \\ 3 Key Laboratory of Plant Nutrition and Fertilizer in South Region, Ministry of Agriculture, Institute of \\ Agricultural Resources and Environment, Guangdong Academy of Agricultural Sciences, \\ Guangzhou 510640, China; pzx007@163.com \\ 4 Guangdong Key Laboratory of Nutrient Cycling and Farmland Conservation, Institute of Agricultural \\ Resources and Environment, Guangdong Academy of Agricultural Sciences, Guangzhou 510640, China \\ 5 Department of Plant Breeding and Genetics, The University of Haripur, Haripur 22620, Khyber \\ Pakhtunkhwa, Pakistan; drizharhussain29@163.com \\ 6 College of Water Resources and Architectural Engineering, Northwest Agriculture \& Forestry University, \\ Yangling 712100, China; tehseenjaved18@yahoo.com \\ 7 Faculty of Crop Protection Sciences, the University of Agriculture, Peshawar 25130, Khyber Pakhtunkhwa, \\ Pakistan; misbahullah119@gmail.com \\ * Correspondence: guwenjie0818@163.com (W.G.); hanqf88@nwsuaf.edu.cn (Q.H.) \\ + These authors contributed equally.
}

Received: 17 December 2019; Accepted: 23 January 2020; Published: 29 January 2020

\begin{abstract}
In the present study, we examined the potential role of paclobutrazol in delaying leaf senescence, in causing changes in the activities of antioxidants, and in the maintenance of photosynthetic activity during the senescence process, and, therefore, on the grain yield of maize under semiarid field conditions. Maize seeds were pretreated with 0 (CK), 200 (PS1), 300 (PS2), and 400 (PS3) $\mathrm{mg}$ paclobutrazol $\mathrm{L}^{-1}$. Our results indicated that elevated levels of reactive oxygen species (ROS) and higher accumulation of malondialdehyde (MDA) contents were positively associated with accelerated leaf senescence during the grain-filling periods. The leaf senescence resulted in the disintegration of the photosynthetic pigments and reduced the net photosynthetic rate after silking. However, the resultant $\mathrm{ROS}$ burst $\left(\mathrm{O}_{2}{ }^{-}\right.$and $\left.\mathrm{H}_{2} \mathrm{O}_{2}\right)$ was lessened and the leaf senescence and chlorophyll degradation were evidently inhibited in leaves of paclobutrazol-treated maize plants, which was strongly linked with upregulated activities of antioxidant enzymes in treated plants. The enhanced chlorophyll contents and availability of a greater photosynthetic active green leaf area during the grain filling period facilitated the maintenance of higher photosynthetic rate, and light-harvesting efficiency of photosynthesis associated with photosystem II (PSII) resulted in higher kernel number ear ${ }^{-1}$ and thousand kernel weights, and thus increased the final grain yield. The average maize grain yield was increased by $18.8 \%$ to $55.6 \%$ in paclobutrazol treatments, compared to untreated control. Among the various paclobutrazol treatments, PS2 $\left(300 \mathrm{mg} \mathrm{L}^{-1}\right)$ treatment showed the most promising effects on enhancing the activities of antioxidative enzymes, delaying
\end{abstract}


leaf senescence and improving the yield of maize. Thus, understanding this effect of paclobutrazol on delaying leaf senescence introduces new possibilities for facilitating yield improvement of maize under semiarid conditions.

Keywords: senescence; antioxidant enzymes; chlorophyll; photosynthesis; Zea mays L.

\section{Introduction}

Maize is one of the world's most important summer crops, which is used not only as a staple food crop but also as animal feed, bioenergy, and industrial crop [1]. In recent years, it is rapidly transforming into an economically vital industrial commodity in Asia [2], and with the rapid expansion of the global population, the demand for maize is further rising [1]. In China, the majority of the maize-cultivated areas are dominated in the arid and semiarid region of the northwestern Loess Plateau, characterized by low rainfall and water scarcity, and drought span often prevails during the maize growing periods [3]. The precipitation in these regions (250-600 $\mathrm{mm}$ each year) during the crop growing season is always insufficient to meet the crop water requirements (500-800 $\mathrm{mm}$ ) for higher maize productivity [4]. The limited and erratic precipitation accelerates the early onset of leaf senescence and often reduces yields [5].

Leaves are the prime photosynthetic organs and hence a major source for carbon assimilation and crop growth of plants [6]. Chlorophyll, as primary photosynthetic pigments in leaves, facilitate the process of photosynthesis by effectively utilizing solar energy, and, hence, plant growth and development continues [4,7]. However, after reaching the reproductive stage, leaf chlorophyll contents gradually degrade with the onset of leaf senescence, which seriously declines the photosynthetic capacity $[8,9]$. Although leaf senescence is a natural phenomenon associated with aging, the rate and timing of leaf senescence can be significantly influenced by several environmental perturbations $[7,10]$. Under semiarid water deficit regions, the senescence often starts before the complete development of all leaf area and progresses at an increased rate during the grain filling period [5]. Leaf senescence causes the disintegration of chlorophyll pigments, inhibition of photosynthesis-related protein and enzymes, thereby reducing the overall photosynthetic capacity [11,12]. In maize, the grain-filling process is greatly dependent on the active photosynthetic area, and the photo-assimilates formed after silking contributes to more than $80 \%$ of the grain yields $[8,13]$. So, it is envisioned that extending the photosynthetic duration by delaying leaf senescence and degradation of photosynthetic pigments during the grain-filling stage could possibly facilitate maize productivity and grain yield.

Leaf senescence is associated with an increase in the levels of reactive oxygen species (ROS), which can cause injuries in different parts of the plant, such as peroxidation of membrane, proteins, DNA, and RNA, that lead to cell death in extreme situations $[11,14,15]$. Oxidative stress reduces the flow of electrons in the photosynthetic electron transport chain, disrupting the activities of reaction centers (P700 for PSI and P680 for PSII), and retard the biosynthesis of chlorophyll molecules $[7,16]$. To maintain ROS homeostasis and to lessen the oxidative stress, plant cells are well furnished with inherent defensive agents, comprised of enzymatic antioxidants, such as SOD (superoxide dismutase), CAT (catalase), POD (peroxidase), and APX (ascorbate peroxidases), and the non-enzymatic antioxidants including ascorbate (AsA), glutathione (GSH), and tocopherols $[9,17,18]$. The activities of these antioxidants play important roles in governing ROS levels under stress environments and protecting plant cells against free radical damage $[8,19]$. Therefore, strategies for enhancing the efficiency of antioxidant defense systems are imperative for extending leaf longevity and for facilitating plant's nature of adaptations under the semiarid region with limited water for sustainable agricultural productivity.

Paclobutrazol is a derivative of the triazole group and is a potent plant growth regulator and fungicide. Paclobutrazol has been widely employed in agriculture for the fine-tuning of plant canopies in the desired way [20-23]. In fact, our previous studies have also portrayed its potential in 
improving lodging resistance in wheat and maize [24,25]. Interestingly, few studies have reported the potential of various triazoles in improving the levels of chlorophyll, antioxidants, and proline contents under various abiotic stresses, and extending the plant growth cycle by delaying physiological maturity $[7,18,19,26,27]$. However, the results of these studies are limited to only pot experiments, and the effects of paclobutrazol on biochemical and physiological indices and the leaf senescence process in field crops is still lacking. Taking into account the lack of information, we carried out this work aiming to understand the regulatory effects of paclobutrazol on the interactions among leaf senescence, levels of ROS, and the activities of ROS scavenging enzymes, and its possible role in the protection of photosynthetic organs during leaf senescence and improvements in maize productivity in semiarid regions.

\section{Materials and Methods}

\subsection{Site Description}

Field experiments were carried out in the years 2014 and 2015 at the Dryland Farming Experimental Station of Northwest A\&F University, Yangling ( $34^{\circ} 20^{\prime} \mathrm{N}, 108^{\circ} 04^{\prime} \mathrm{E}, 466.7 \mathrm{~m}$ above sea level) in northwestern China. This semiarid Loess Plateau region is characterized by a warm temperate and drought-prone climate. The soil is Cumuli-Ustic Isohumosols (light silt loam) according to the Chinese Soil Taxonomy containing $14.02 \mathrm{~g} \mathrm{~kg}^{-1}$ organic matter, $0.79 \mathrm{~g} \mathrm{~kg}^{-1}$ total nitrogen, $55.21 \mathrm{mg} \mathrm{kg}^{-1}$ available nitrogen, $25.23 \mathrm{mg} \mathrm{kg}^{-1}$ available phosphorus, and $95.42 \mathrm{mg} \mathrm{kg}^{-1}$ available potassium in the upper $40 \mathrm{~cm}$ soil profile. Over the last 40 years, the mean annual precipitation at the experimental area was $580 \mathrm{~mm}$ and the annual average temperature ranged from $12.5 \pm 2{ }^{\circ} \mathrm{C}$. The precipitation and air temperature during the two growing seasons are presented in Figure 1.

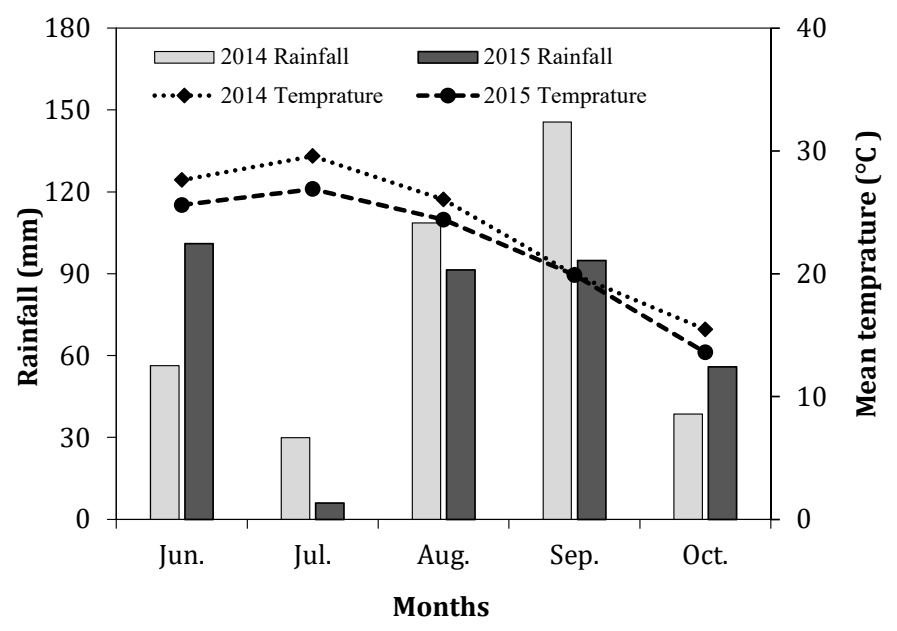

Figure 1. Mean temperature $\left({ }^{\circ} \mathrm{C}\right)$ and precipitation $(\mathrm{mm})$ during 2014 and 2015 maize growing seasons at the experimental site.

\subsection{Seed Treatment and Experimental Design}

A popular and widely cultivated summer maize hybrid for local production, Zhengdan958 (ZD 958), was used in the present experiment. Seeds were surface sterilized with $3 \% \mathrm{NaOCl}$ solution for $15 \mathrm{~min}$. After rinsing several times with distilled water, the maize seeds were primed with different concentrations of paclobutrazol including 0 (Control, CK), 200 (PS1), 300 (PS2), and 400 (PS3) $\mathrm{mg} \mathrm{L}^{-1}$ for $12 \mathrm{~h}$ at $25^{\circ} \mathrm{C}$. For the control treatment, seeds were primed with distilled water.

The experimental design was a randomized block with three replications in both study years. Each plot size was $35 \mathrm{~m}^{2}$ (7 m long and $5 \mathrm{~m}$ wide) with interplant space $17 \mathrm{~cm}$ and row spacing $60 \mathrm{~cm}$, and plant density of 97,500 plants $_{\text {ha }}{ }^{-1}$ was maintained. Maize seeds were manually sown on June 14 and 16 and were harvested on October 11 and 14 in the years 2014 and 2015, respectively. During 
both crop growing seasons, a basal fertilizer of $120 \mathrm{~kg}^{\text {Nitrogen ha }}{ }^{-1}(\mathrm{~N}), 150 \mathrm{~kg}$ Phosphorus ha ${ }^{-1}$ $\left(\mathrm{P}_{2} \mathrm{O}_{5}\right)$, and $120 \mathrm{~kg}$ Potassium ha ${ }^{-1}\left(\mathrm{~K}_{2} \mathrm{O}\right)$ was used at sowing, based on local practice. An additional $120 \mathrm{~kg} \mathrm{~N} \mathrm{ha}^{-1}$ was also used at early flowering. During the two growing seasons, the crop was solely dependent on natural precipitation and weeds and pests were effectively controlled throughout the growing seasons.

\subsection{Plants Sampling and Measurements}

Plant sampling and measurement were carried out at the central five rows in each treatment to minimize the edge effects. Plant samples were collected at 0 DAS (days after silking), 15 DAS, 30 DAS, and 45 DAS for the determination of green leaf area, chlorophyll content, antioxidants enzymes activities, ROS, soluble protein, soluble sugar, and MDA contents in both study years.

\subsubsection{Determination of Green Leaf Area and Senescence Rate}

For the determination of leaf area and senescence, five maize plants were randomly selected from each plot at various stages $(0,15,30$, and 45 DAS). The leaf area of the five sampled plants was determined manually by measuring the leaf length and maximum leaf width (Leaf area $=$ leaf length $\times$ maximum leaf width $\times 0.75$ ). A leaf was considered senescent leaf when half or more of its area had turned yellow. The rate of leaf senescence was measured according to the formula: leaf senescence rate $=\Delta \mathrm{LA} / \Delta \mathrm{T}$.

$\Delta \mathrm{LA}$ indicates the change in leaf area plant ${ }^{-1}$ during two sampling intervals and $\Delta \mathrm{T}$ is the time interval.

\subsubsection{Assay of Chlorophyll and Carotenoid Content}

Leaf chlorophyll and carotenoids were measured following the standard protocol of Arnon [28]. An aliquot of fresh leaves $(0.5 \mathrm{~g})$ was suspended in $10 \mathrm{~mL}$ of acetone $(80 \%)$ and kept at room temperature in the dark overnight. Next, the samples were centrifuged $(5000 \times \mathrm{g})$ for $15 \mathrm{~min}$, and the absorbance of the resultant supernatants was recorded at $645 \mathrm{~nm}, 663 \mathrm{~nm}$, and $480 \mathrm{~nm}$ using a spectrophotometer. The contents of chlorophyll and carotenoids were presented as $\mathrm{mg} \mathrm{g}^{-1}$ fresh weight (FW).

\subsubsection{Net Photosynthetic Rate and Chlorophyll Fluorescence Analysis}

For measuring the net photosynthesis rate (Pn), five representative plants were selected from each treatment and the Pn values of fully expanded penultimate leaf (third leaf from top) was measured using a portable LI-6400 instrument (LI-COR Inc., Lincoln, NE, USA) at 0, 15, 30, and 45 DAS. The measurements were carried out on a clear and sunny day from 9:00 to 11:00 a.m.

Fluorescence parameters of intact leaves were determined by using a portable chlorophyll fluorescence machine (PAM-2500, Walz, Effeltrich, Germany) as described by Wang et al. [9]. The minimal fluorescence (Fo) was measured after applying weak modulated irradiation $\left(<0.1 \mu \mathrm{mol} / \mathrm{m}^{2} / \mathrm{s}\right)$ for $6 \mathrm{~s}$. The maximum chlorophyll fluorescence yield (Fm) was determined after $1 \mathrm{~h}$ dark period adaptation by applying a saturating flash $\left(>7000 \mu \mathrm{mol} / \mathrm{m}^{2} / \mathrm{s}\right)$ for $0.8 \mathrm{~s}$. The actinic light intensity was set at $600 \mu \mathrm{mol} / \mathrm{m}^{2} / \mathrm{s}$ for analyzing steady-state fluorescence (Fs), maximum fluorescence (Fm'), and initial fluorescence $\left(\mathrm{F0}^{\prime}\right)$. The maximal photochemical efficiency of PSII was determined as $\mathrm{Fv} / \mathrm{Fm}=$ $(\mathrm{Fm}-\mathrm{Fo}) / \mathrm{Fm}$, and the actual photochemical efficiency of PSII in the light is $\mathrm{Y}(\mathrm{II})=\left(\mathrm{Fm}^{\prime}-\mathrm{Fs}\right) / \mathrm{Fm}^{\prime}$.

\subsubsection{Preparation of Enzyme Extracts and Assay of Antioxidant Enzymes}

For the assay of antioxidant enzymes, ear leaf samples $(0.5 \mathrm{~g})$ with midrib removed were homogenized with $5 \mathrm{~mL}$ phosphate buffer $(0.1 \mathrm{M}, \mathrm{pH}$ 6.8). The homogenates followed a centrifuge $(15,000 \times g$ for 10$)$ at $4{ }^{\circ} \mathrm{C}$ for $30 \mathrm{~min}$ and the resultant supernatants were used for the determination of superoxide dismutase (SOD), ascorbate peroxidase (APX), catalase (CAT), peroxidase (POD), and soluble protein contents. The enzyme activities were presented as $\mathrm{U} \mathrm{mg}^{-1} \mathrm{FW}$. 
The SOD activity was assayed using the standard protocol of Giannopolitis and Ries [29] following the NBT (nitro blue tetrazolium) photo-reduction. The enzyme extract $(20 \mu \mathrm{L})$ was added into the SOD reaction mixture containing $1.5 \mathrm{~mL}$ phosphate buffer $(50 \mathrm{mM}, \mathrm{pH} 7.8), 0.3 \mathrm{~mL}$ methionine $(13 \mathrm{mM})$, $0.3 \mathrm{~mL}$ NBT $(750 \mathrm{mM}), 0.3 \mathrm{~mL}$ EDTA-Na $2(0.1 \mathrm{mM}), 0.3 \mathrm{~mL}$ riboflavin $(20 \mathrm{M})$, and $0.3 \mathrm{~mL}$ distilled water. The absorbance of the solutions was recorded at $560 \mathrm{~nm}$ using a spectrophotometer.

The activity of POD was estimated following the procedures of Ekmekci and Terzioglu [30], with slight changes. The enzyme extract $(20 \mu \mathrm{L})$ was added to the POD reaction mixture containing $1.5 \mathrm{~mL}$ phosphate buffer ( $50 \mathrm{mM}$, pH 7.8), $0.5 \mathrm{~mL} \mathrm{H}_{2} \mathrm{O}_{2}(200 \mathrm{mM}), 0.5 \mathrm{~mL}$ guaiacol $(50 \mathrm{mM})$, and $0.5 \mathrm{~mL}$ distilled water. For calculating POD activity, the increase in absorbance due to guaiacol oxidation at $470 \mathrm{~nm}$ was recorded using a spectrophotometer.

The activity of CAT was estimated according to the procedures explained by Wang et al. [8]. Enzyme extract $(20 \mu \mathrm{L})$ was mixed with the CAT reaction mixture consisting of $2 \mathrm{~mL}$ phosphate buffer $\left(50 \mathrm{mM}, \mathrm{pH} 7.0\right.$ containing $0.1 \mathrm{mM}$ EDTA) and $0.5 \mathrm{~mL} \mathrm{H}_{2} \mathrm{O}_{2}(100 \mathrm{mM})$. The reaction was initiated after the addition of $\mathrm{H}_{2} \mathrm{O}_{2}$ and the rate of $\mathrm{H}_{2} \mathrm{O}_{2}$ decomposition was measured at $240 \mathrm{~nm}$ with a spectrophotometer.

The activity of APX was assayed following the method of Nakano and Asada [31]. A volume of $0.1 \mathrm{~mL}$ enzyme extract was mixed with $3 \mathrm{~mL}$ reaction mixture containing phosphate buffer $(50 \mathrm{mM}$, $\mathrm{pH}$ 7.0), $0.5 \mathrm{mM}$ ascorbic acid, $0.2 \mathrm{mM}$ EDTA, and $0.1 \mathrm{mM} \mathrm{H}_{2} \mathrm{O}_{2}$. The decrease in absorbance due to ascorbate oxidation was monitored at $290 \mathrm{~nm}$ with a spectrophotometer.

\subsubsection{Estimation of Soluble Sugars and Protein}

The content of soluble sugar was determined according to the anthrone method as explained by Wang et al. [8]. Briefly, leaf samples (0.2 g) were homogenized with $5 \mathrm{~mL}$ of ethanol ( $96 \%$ ) followed by centrifugation $(3500 \times \mathrm{g})$ for $10 \mathrm{~min}$. The supernatant $(0.1 \mathrm{~mL})$ was added to $3 \mathrm{~mL}$ of anthrone reagent $\left(150 \mathrm{mg}\right.$ anthrone $+100 \mathrm{~mL}$ concentrated $\mathrm{H}_{2} \mathrm{SO}_{4}$ ) and the mixture was incubated in a boiling water bath for $10 \mathrm{~min}$. After cooling, the absorbance of the mixture was recorded at $625 \mathrm{~nm}$ using a spectrophotometer.

The concentration of soluble protein was determined following the Coomassie brilliant blue G-250 staining method, as explained by Zhao et al. [11]. The concentration of protein was expressed as $\mathrm{mg} \mathrm{g}^{-1} \mathrm{FW}$.

\subsubsection{Determination of Malonaldehyde (MDA) and Reactive Oxygen Species (ROS)}

MDA contents as a biomarker of lipid peroxidation were determined following the procedure of Heath and Packer [32]. Briefly, leaf samples $(0.5 \mathrm{~g})$ were extracted with $10 \mathrm{~mL}$ ethanol, followed by centrifugation $(4000 \times \mathrm{g})$ at $25^{\circ} \mathrm{C}$ for $10 \mathrm{~min}$. The extracts $(1 \mathrm{~mL})$ were added to a $2 \mathrm{~mL}$ reaction mixture ( $20 \%$ trichloroacetic acid and $0.65 \%$ thiobarbituric acid) in a test tube. The samples were heated in a water bath at $100{ }^{\circ} \mathrm{C}$ for $20 \mathrm{~min}$ and centrifuged $(10,000 \times \mathrm{g})$ for $5 \mathrm{~min}$ after cooling. The absorbance of the samples was recorded at 440, 532, and 600, and MDA contents were expressed in nmol g ${ }^{-1} \mathrm{FW}$.

The rate of $\mathrm{O}_{2}{ }^{-}$generation was measured following the modified protocol of Zhang et al. [33]. In total, $0.2 \mathrm{~g}$ of leaf samples were extracted in $1 \mathrm{~mL}$ phosphate buffer $(50 \mathrm{mM}, \mathrm{pH} 7.8)$, followed by centrifugation $(10,000 \times \mathrm{g})$. Thereafter, $1 \mathrm{~mL}$ of supernatant was mixed with the reaction mixture containing sulphanilamide $(17 \mathrm{mM})$ and naphthalene diamine hydrochloride $(7 \mathrm{mM})$. The resultant mixture was incubated at $37^{\circ} \mathrm{C}$ for $10 \mathrm{~min}$ and $3 \mathrm{~mL}$ ether was added to each tube. The samples were centrifuged $\left(5000 \times \mathrm{g}\right.$ ) for $5 \mathrm{~min}$ at $24^{\circ} \mathrm{C}$, and the absorbance was spectrophotometrically recorded at $540 \mathrm{~nm} . \mathrm{O}_{2}^{-}$contents were calculated as nmol $\mathrm{min}^{-1} \mathrm{~g}^{-1} \mathrm{FW}$.

$\mathrm{H}_{2} \mathrm{O}_{2}$ was quantified by the addition of $200 \mathrm{~mL}$ enzyme extract to the reaction mixture containing phosphate buffer ( $2.5 \mathrm{mM}, \mathrm{pH} 7.0)$ and potassium iodide $(500 \mathrm{mM})$ [33]. The reaction mixture was incubated for $1 \mathrm{~h}$ at $25^{\circ} \mathrm{C}$ under dark and the absorbance was recorded at $390 \mathrm{~nm}$ against $\mathrm{H}_{2} \mathrm{O}_{2}$ as a standard. $\mathrm{H}_{2} \mathrm{O}_{2}$ contents were expressed as nmol g ${ }^{-1} \mathrm{FW}$. 


\subsubsection{Grain Yield and Yield Components}

At physiological maturity, the grain yield and yield components were determined by randomly selecting and harvesting an area of $9.6 \mathrm{~m}^{2}(4 \mathrm{~m} \times 4$ rows $)$ at the center of each plot. Thirty representative plants from each sampling area were used for measuring the ear length and ear diameter, the number of kernel per ear, and thousand kernel weight (TKW). Grain yield was expressed at $14.0 \%$ moisture content.

\subsection{Statistical Analysis}

The effects of the treatments on the measured parameters were evaluated by two-way analysis of variance (ANOVA) according to the General Linear Model (GLM) using SPSS version 16.0. The data from each sampling event were separately analyzed and the significant differences between treatments' mean were based on Fisher's least significant difference (LSD) test at $P<0.05$. Using Pearson's correlation coefficient, simple correlation analyses were employed to identify the relationship of leaf senesces rate with antioxidant enzymes, photosynthetic rate, and grain yield.

\section{Results}

\subsection{Ear Size}

Paclobutrazol treatments $(\mathrm{P})$ and year $(\mathrm{Y})$ significantly affected the ear size of maize, but no-significant interaction for $\mathrm{P} \times \mathrm{Y}$ was detected (Table 1). The ear length and diameter were increased significantly with the application of different paclobutrazol treatments compared to control (CK) from 2014 to 2015 (Table 2). The ear length of PS1-, PS2-, and PS3-treated plants was greater by $19.4 \%, 34.4 \%$, and $19.9 \%$ in 2014 , while it was greater by $11.4 \%, 30.4 \%$, and $21.7 \%$ in 2015 , compared to control, respectively. Similarly, the ear diameter in PS1-, PS2-, and PS3-treated plants were increased by $14.2 \%$, $15.4 \%$, and $17.1 \%$ in 2014 , and it was increased by $4.1 \%, 12.4 \%$, and $10.0 \%$ in 2015 , respectively (Table 1 ).

Table 1. Results of ANOVA on the effects of the year $(\mathrm{Y})$ and paclobutrazol $(\mathrm{P})$ on the ear size, grain yield, and yield components of maize.

\begin{tabular}{|c|c|c|c|c|c|c|}
\hline Effect & $\mathrm{df}$ & Ear Length & Ear Diameter & Kernels Ear-1 & TKW & Grain Yield \\
\hline Year (Y) & 1 & $8.21^{*}$ & $28.57^{* *}$ & $12.10^{* *}$ & $14.62^{* *}$ & $25.58^{* *}$ \\
\hline $\begin{array}{l}\text { Paclobutrazol } \\
\text { (P) }\end{array}$ & 3 & $72.57^{* *}$ & $96.86^{* *}$ & $114.42^{* *}$ & $174.56^{* *}$ & $183.60^{* *}$ \\
\hline $\mathrm{Y} \times \mathrm{P}$ & 3 & $0.93^{\mathrm{NS}}$ & $2.86^{\mathrm{NS}}$ & $0.42^{\mathrm{NS}}$ & $1.37^{\mathrm{NS}}$ & $1.99 \mathrm{NS}$ \\
\hline
\end{tabular}

\subsection{Grain Yield And Yield Components}

Paclobutrazol treatments and year showed a significant effect on TKW and the number of kernels but the interaction of $\mathrm{P} \times \mathrm{Y}$ was not significant (Table 1). The TKW and number of kernels in all treatments were greater by 3.6\% and 3.9\%, respectively, in 2014 than in 2015 (Table 2). Moreover, paclobutrazol application treatments significantly increased the TKW and kernel number compared to untreated control, and the greatest effect was perceived in PS2-treated maize plants in both years. When compared to control, the PS2 treatment increased the TKW and kernel numbers by $28.2 \%$ and $21.9 \%$ in 2014 , while it was increased by $25.9 \%$ and $22.6 \%$ in 2015 , respectively (Table 2). The PS3 treatment inhibited the plant growth and decreased the TKW and kernels number compared to PS2; however, they were greater than that in control plants. 
Table 2. Effects of paclobutrazol treatments on ear size, grain yield, and yield components of maize during 2014 and 2015.

\begin{tabular}{ccccccc}
\hline Year & Treatments & $\begin{array}{c}\text { Ear Length } \\
\mathbf{( c m})\end{array}$ & $\begin{array}{c}\text { Ear Diameter } \\
\mathbf{( c m )}\end{array}$ & Kernels ear $\mathbf{- 1}$ & TKW $(\mathbf{g})$ & $\begin{array}{c}\text { Grain Yield } \\
\mathbf{t ~ h a}^{-1} \mathbf{)}\end{array}$ \\
\hline \multirow{2}{*}{$\mathbf{2 0 1 4}$} & CK & $14.1 \pm 0.45 \mathrm{~d}$ & $4.3 \pm 0.06 \mathrm{c}$ & $403 \pm 12.02 \mathrm{~d}$ & $264.6 \pm 6.04 \mathrm{~d}$ & $6.50 \pm 0.25 \mathrm{~d}$ \\
& PS1 & $15.4 \pm 0.56 \mathrm{c}$ & $4.6 \pm 0.07 \mathrm{~b}$ & $454 \pm 9.38 \mathrm{c}$ & $312.1 \pm 2.40 \mathrm{c}$ & $8.03 \pm 0.30 \mathrm{c}$ \\
& PS2 & $18.9 \pm 0.71 \mathrm{a}$ & $5.0 \pm 0.07 \mathrm{a}$ & $535 \pm 8.35 \mathrm{a}$ & $360.0 \pm 7.38 \mathrm{a}$ & $10.45 \pm 0.29 \mathrm{a}$ \\
& PS3 & $16.8 \pm 0.47 \mathrm{~b}$ & $5.0 \pm 0.09 \mathrm{a}$ & $491 \pm 13.21 \mathrm{~b}$ & $339.1 \pm 6.71 \mathrm{~b}$ & $9.23 \pm 0.23 \mathrm{~b}$ \\
& CK & $13.5 \pm 0.52 \mathrm{~d}$ & $4.2 \pm 0.09 \mathrm{c}$ & $390 \pm 6.55 \mathrm{~d}$ & $257.2 \pm 6.09 \mathrm{c}$ & $6.37 \pm 0.26 \mathrm{~d}$ \\
& PS1 & $15.0 \pm 0.49 \mathrm{c}$ & $4.4 \pm 0.05 \mathrm{~b}$ & $438 \pm 11.93 \mathrm{c}$ & $308.4 \pm 9.23 \mathrm{~b}$ & $7.28 \pm 0.19 \mathrm{c}$ \\
& PS2 & $17.6 \pm 0.72 \mathrm{a}$ & $4.8 \pm 0.05 \mathrm{a}$ & $508 \pm 9.07 \mathrm{a}$ & $341.6 \pm 7.62 \mathrm{a}$ & $9.59 \pm 0.37 \mathrm{a}$ \\
& PS3 & $16.4 \pm 0.38 \mathrm{~b}$ & $4.7 \pm 0.06 \mathrm{a}$ & $478 \pm 14.80 \mathrm{~b}$ & $323.8 \pm 9.45 \mathrm{~b}$ & $8.65 \pm 0.33 \mathrm{~b}$ \\
\hline
\end{tabular}

Data are presented as mean \pm SD of three measurements. Different small letters $(\mathrm{a}, \mathrm{b}, \mathrm{c}, \mathrm{d})$ in each column indicate significant differences at $P<0.05$ (least significant difference (LSD) test). TKW, thousand kernel weight; CK, PS1, PS2, and PS3 represent seed treatment with paclobutrazol at the rate of $0,200,300$, and $400 \mathrm{mg} \mathrm{L}^{-1}$, respectively.

Similarly, the grain yield was significantly affected by paclobutrazol treatments and year but their interaction was not significant (Table 1). The average grain yield in 2014 was greater by $7.3 \%$ than in 2015. The paclobutrazol treatments evidently increased the grain yield with the highest yield achieved by PS2 treatment associated with the greater TKW and kernel number. When compared to untreated control plants, the grain yield of PS1-, PS2-, and PS3-treated plants was greater by $23.5 \%, 60.8 \%$, and $42.0 \%$ in 2014 , and it was greater by $14.2 \%, 50.4 \%$, and $35.7 \%$ in 2015 , respectively (Table 2 ).

\subsection{Leaf Senescence Rate}

The leaf senescence rate in maize crop during the two growing seasons was described by an exponential curve, see Figure 2. Paclobutrazol treatments and the sampling times showed significant effects on the leaf senescence rate. The interactions among various factors were also significant (Table 3 ). The rate of leaf senescence was significantly greater (19.8\%) in 2015 than in 2014. The results also indicated that the rate of leaf senescence was relatively low at 15 and 30 DAS, but sharply increased after grain filling period to physiological maturity, indicating a rapid degradation of green leaf area. Nevertheless, paclobutrazol treatments, particularly the PS2 and PS3 treatments maintained greater green leaf area even at the later growth stages (30 to 45 DAS) by inhibiting the leaf senescence during both crop growing seasons. The two years (2014 and 2015) mean results showed that the leaf senescence rate in PS2- and PS3-treated plants was decreased by $58.5 \%$ and $58.2 \%$ at 15 DAS, $61.5 \%$ and $53.6 \%$ at 30 DAS, $58.0 \%$ and $47.2 \%$ at 45 DAS, and $49.8 \%$ and $39.4 \%$ at 60 DAS, compared to untreated control plants (Figure 2).

\subsection{Effect of Paclobutrazol on Photosynthetic Pigments}

Paclobutrazol treatments, sampling times, and year showed significant effects on total chlorophyll contents. In addition, the interaction among the various factors was non-significant, except for $\mathrm{P}$ $\times \mathrm{T}$ (Table 3 ). With the progression of days after silking, chlorophyll contents gradually declined in all treatments. However, the degradation of photosynthetic pigments was markedly inhibited in paclobutrazol treatments compared to control treatment (Figure 3A). The PS2-treated plants maintained higher chlorophyll contents throughout the growing season during both years (2014-2015). However, the chlorophyll content in PS3 treatment was inhibited than that in PS2 treatment and was similar to that in PS1 treatment at various sampling stages. The two years' mean results portrayed that the chlorophyll content of PS1, PS2, and PS3 treatments were increased by $22.4 \%, 48.2 \%$, and $36.9 \%$ at 0 DAS, $32.1 \%, 54.3 \%$, and $38.2 \%$ at 15 DAS, $26.3 \%, 51.2 \%$, and $27.8 \%$ at 30 DAS, $30.2 \%, 79.0 \%, 32.2 \%$ at 45 DAS, compared to control treatment, respectively (Figure 3A). 

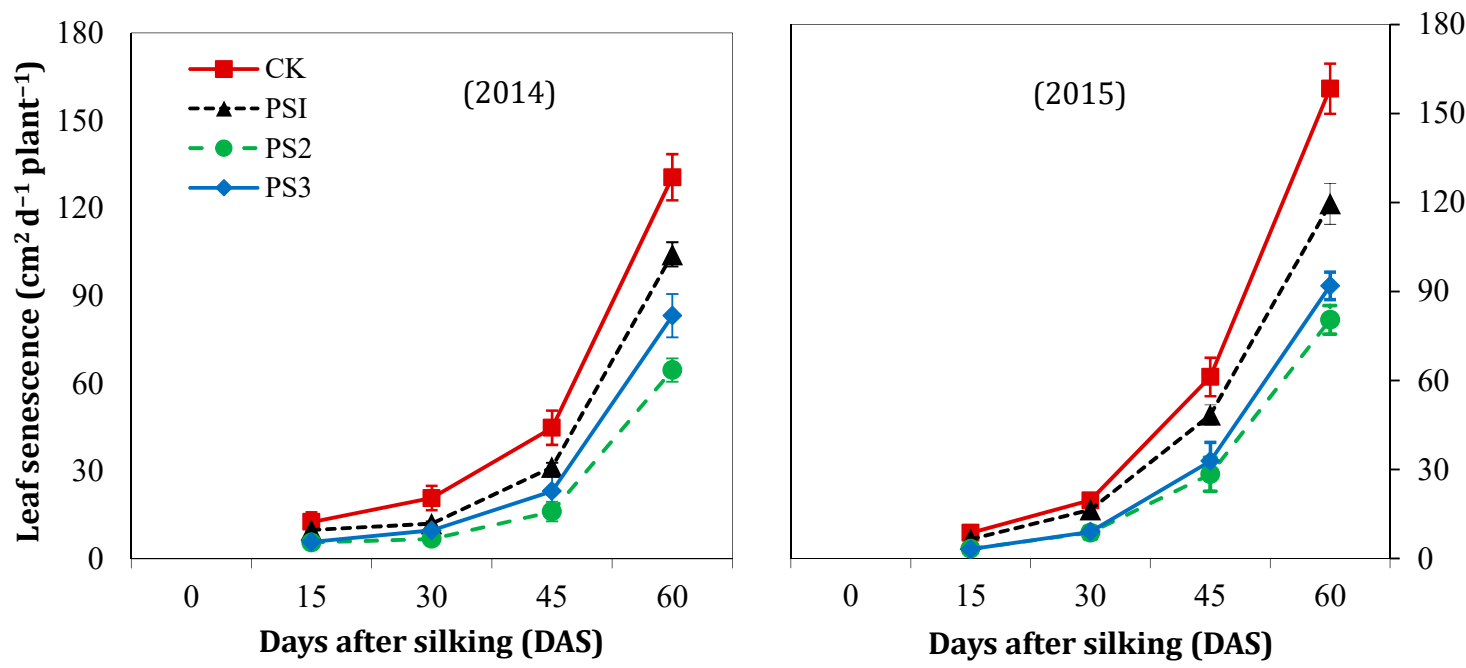

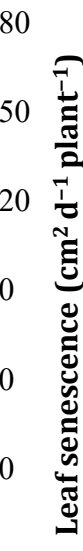

Figure 2. Effects of paclobutrazol treatments on the leaf senescence rate in maize during 2014 and 2015. Data are presented as mean \pm SD of three measurements. CK, PS1, PS2, and PS3 represent seed treatment with paclobutrazol at the rate of $0,200,300$, and $400 \mathrm{mg} \mathrm{L}^{-1}$, respectively.
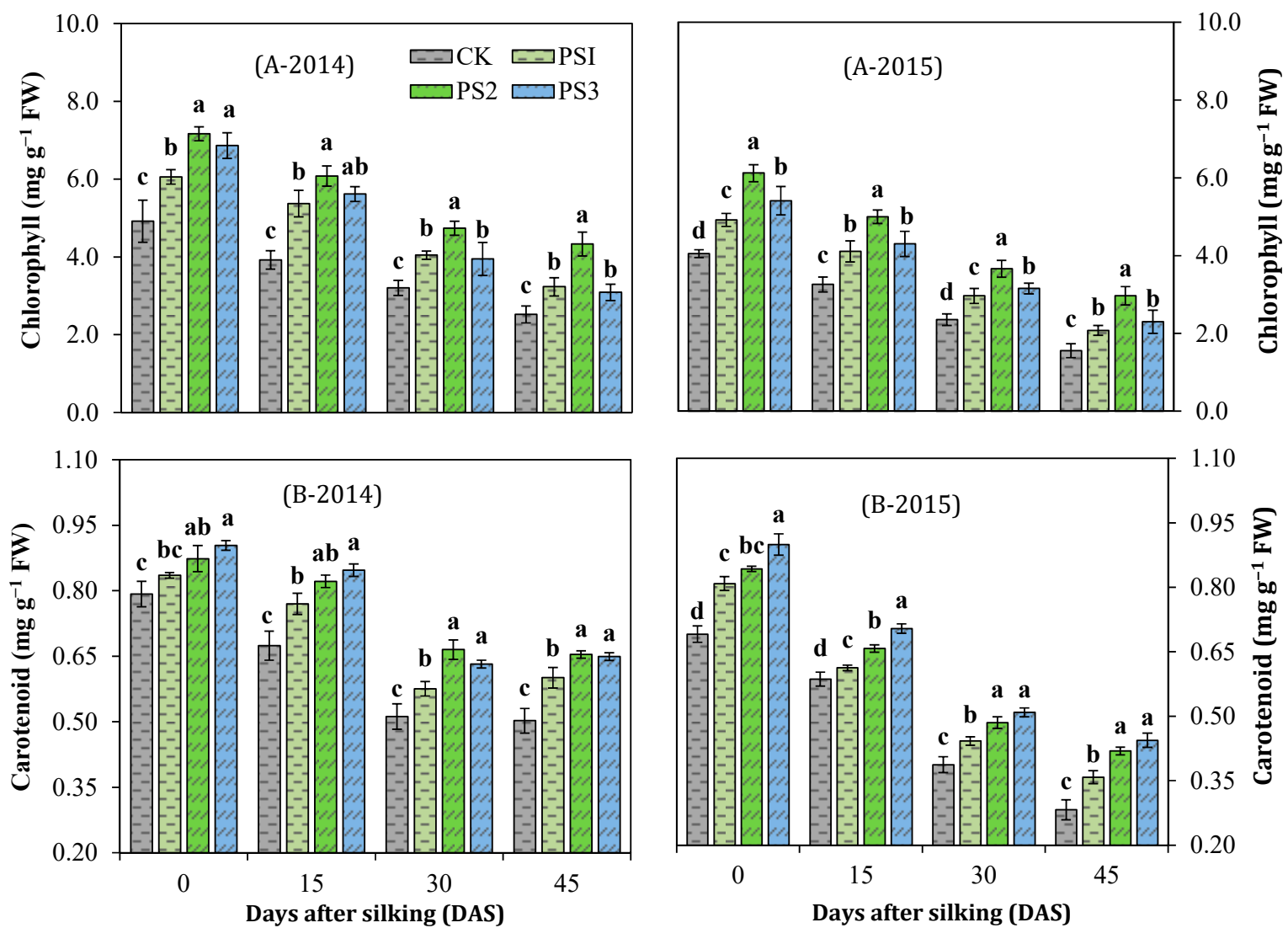

Figure 3. Effects of paclobutrazol treatments on (A) chlorophyll and (B) carotenoid contents in maize leaves during 2014 and 2015. Data are presented as mean \pm SD of three measurements. Different small letters $(\mathrm{a}, \mathrm{b}, \mathrm{c}, \mathrm{d}, \mathrm{ab}, \mathrm{bc})$ on the bars indicate significant differences at $P<0.05$ (LSD test). The abbreviations of treatment names are the same as those described in Figure 2. 
Table 3. Result of ANOVA on the effects of the year $(\mathrm{Y})$, paclobutrazol treatments (P), and sampling times (T) on leaf senescence, photosynthetic pigments, net photosynthetic rate, chlorophyll fluorescence parameters, antioxidant enzymes, reactive oxygen species, and lipid peroxidation, soluble protein (SP) and soluble sugar (SS) contents in maize.

\begin{tabular}{|c|c|c|c|c|c|c|c|c|c|}
\hline Effect & df & Leaf Senescence & Chlorophyll & Carotenoid & Pn & Fo & Fv/Fm & YII & MDA \\
\hline Year $(\mathrm{Y})$ & 1 & $117.81^{* *}$ & $462.62^{* *}$ & $1325.96^{* *}$ & $0.56^{\mathrm{NS}}$ & $30.67^{* *}$ & $70.02^{* *}$ & $29.91^{* *}$ & $91.70^{* *}$ \\
\hline Paclobutrazol (P) & 3 & $408.27^{* *}$ & $225.11^{* *}$ & $298.44^{* *}$ & $221.39^{* *}$ & $300.07^{* *}$ & $628.96^{* *}$ & $171.12^{* *}$ & $477.82^{* *}$ \\
\hline sampling time $(\mathrm{T})$ & 3 & $4509.25^{* *}$ & $693.39^{* *}$ & $1837.87^{* *}$ & $1072.89^{* *}$ & $918.36^{* *}$ & $1498.3^{* *}$ & $184.41^{* *}$ & $1887.09^{* *}$ \\
\hline $\mathrm{Y} \times \mathrm{P}$ & 3 & $3.73^{*}$ & $2.33^{N S}$ & $3.46^{*}$ & $1.48^{\mathrm{NS}}$ & $3.27^{*}$ & $21.96^{* *}$ & $0.65^{\mathrm{NS}}$ & $1.84^{\mathrm{NS}}$ \\
\hline $\mathrm{Y} \times \mathrm{T}$ & 3 & $53.24^{* *}$ & $0.59 \mathrm{NS}$ & $102.64^{* *}$ & $8.57^{* *}$ & $9.14^{* *}$ & $18.92^{* *}$ & $3.68^{*}$ & $9.99^{* *}$ \\
\hline $\mathrm{P} \times \mathrm{T}$ & 9 & $93.64^{* *}$ & $4.85^{* *}$ & 2.23 * & $4.86^{* *}$ & $4.88^{* *}$ & $7.67^{* *}$ & 0.93 NS & $27.96^{* *}$ \\
\hline $\mathrm{Y} \times \mathrm{P} \times \mathrm{T}$ & 9 & $2.64^{*}$ & $1.23 \mathrm{NS}$ & $4.75^{* *}$ & $1.73^{\mathrm{NS}}$ & $3.16^{* *}$ & $1.36^{\mathrm{NS}}$ & $0.50 \mathrm{NS}$ & $1.69 \mathrm{NS}$ \\
\hline Effect & $\mathrm{df}$ & SOD & POD & CAT & APX & $\mathrm{H}_{2} \mathrm{O}$ & $\mathrm{O}_{2}^{-}$ & SP & SS \\
\hline Year $(Y)$ & 1 & $3695.57^{* *}$ & $1304.9^{* *}$ & $16.97^{* *}$ & $955.43^{* *}$ & $69.33^{* *}$ & $15.1^{* *}$ & $392.47^{* *}$ & $254.74^{* *}$ \\
\hline Paclobutrazol (P) & 3 & $714.81^{* *}$ & $444.6^{* *}$ & $256.36^{* *}$ & $322.9^{* *}$ & $1011.75^{* *}$ & $363.71^{* *}$ & $204.17^{* *}$ & $6.54^{* *}$ \\
\hline sampling time $(\mathrm{T})$ & 3 & $7328.52^{* *}$ & $1736.32^{* *}$ & $504.36^{* *}$ & $464.7^{* *}$ & $1802^{* *}$ & $419.22^{* *}$ & $1782.02^{* *}$ & $3256.40^{* *}$ \\
\hline $\mathrm{Y} \times \mathrm{P}$ & 3 & $11.05^{* *}$ & $2.16^{\mathrm{NS}}$ & $9.24^{* *}$ & $6.72^{* *}$ & $13.12^{* *}$ & $3.70^{*}$ & $3.29^{*}$ & $31.26^{* *}$ \\
\hline $\mathrm{Y} \times \mathrm{T}$ & 3 & $235.92^{* *}$ & $137.08^{* *}$ & $26.1^{* *}$ & $95.15^{* *}$ & $24.65^{* *}$ & $47.61^{* *}$ & $15.23^{* *}$ & $859.57^{* *}$ \\
\hline $\mathrm{P} \times \mathrm{T}$ & 9 & $12.37^{* *}$ & $7.51^{* *}$ & $4.31^{* *}$ & $4.31^{* *}$ & $101.55^{* *}$ & $18.82^{* *}$ & $1.12^{\mathrm{NS}}$ & $92.74^{* *}$ \\
\hline $\mathrm{Y} \times \mathrm{P} \times \mathrm{T}$ & 9 & $3.24^{* *}$ & $4.93^{* *}$ & $4.86^{* *}$ & $2.62^{*}$ & $17.58^{* *}$ & $2.97^{* *}$ & $1.86^{\mathrm{NS}}$ & $6.62^{* *}$ \\
\hline
\end{tabular}

* F values and significance levels at $P<0.05 ;{ }^{* *} \mathrm{~F}$ values and significance levels at $P<0.01$; ${ }^{\mathrm{NS}} \mathrm{F}$ values and significance levels at $P \geq 0.05$. The df represents degree of freedom 
Paclobutrazol treatments, sampling times, and year showed significant effects on carotenoid contents. The interaction among the various factors was also significant (Table 3). Unlike chlorophyll, carotenoids displayed a positive relationship with the increase in paclobutrazol concentration, and the highest carotenoid contents were perceived in PS3 treatment tracked by PS2 treatment in both years (Figure 3B). Compared to control, the two years' averaged carotenoid contents of PS1-, PS2-, and PS3-treated plants were greater by $10.8 \%, 15.7 \%$, and $21.6 \%$ at 0 DAS, $9.7 \%, 17.3 \%$, and $23.0 \%$ at 15 DAS, $13.2 \%, 27.9 \%$, and $26.9 \%$ at $30 \mathrm{DAS}, 22.2 \%, 36.7 \%$, and $39.3 \%$ at $45 \mathrm{DAS}$, respectively. The increase in chlorophyll was in the order CK $<$ PS1 $\leq$ PS3 $<$ PS2 and for carotenoid was CK $<$ PS1 $<$ PS2 $\leq$ PS3 (Figure 3B).

\subsection{Net Photosynthesis Rate}

The net photosynthesis rate was significantly affected by paclobutrazol treatments and sampling times. The interactions of paclobutrazol and sampling times $(\mathrm{P} \times \mathrm{T})$, and year and sampling times $(\mathrm{Y} \times$ T) was also significant (Table 3$)$. The net photosynthesis rate showed a gradual decline with the increase in days after silking in all treatments (Figure 4). Paclobutrazol application at high concentrations (PS2 and PS3) significantly enhanced the net photosynthesis rate from 0 to 30 DAS, compared to control. However, the highest concentration of paclobutrazol (PS3) inhibited the net photosynthesis rate at the later growth stages (30 and 45 DAS) relative to PS2 treatment, associated with an increased leaf senescence rate. As depicted in Figure 4, among all the treatments, PS2 maintained significantly higher net photosynthetic rate at 0 DAS (greater by $49.5 \%$ and $34.2 \%$ ), 15 DAS (32.5\% and $41.9 \%), 30$ DAS (47.9\% and 55.3\%), and 45 DAS (80.0\% and 84.6\%), compared to control from 2014 to 2015, respectively.
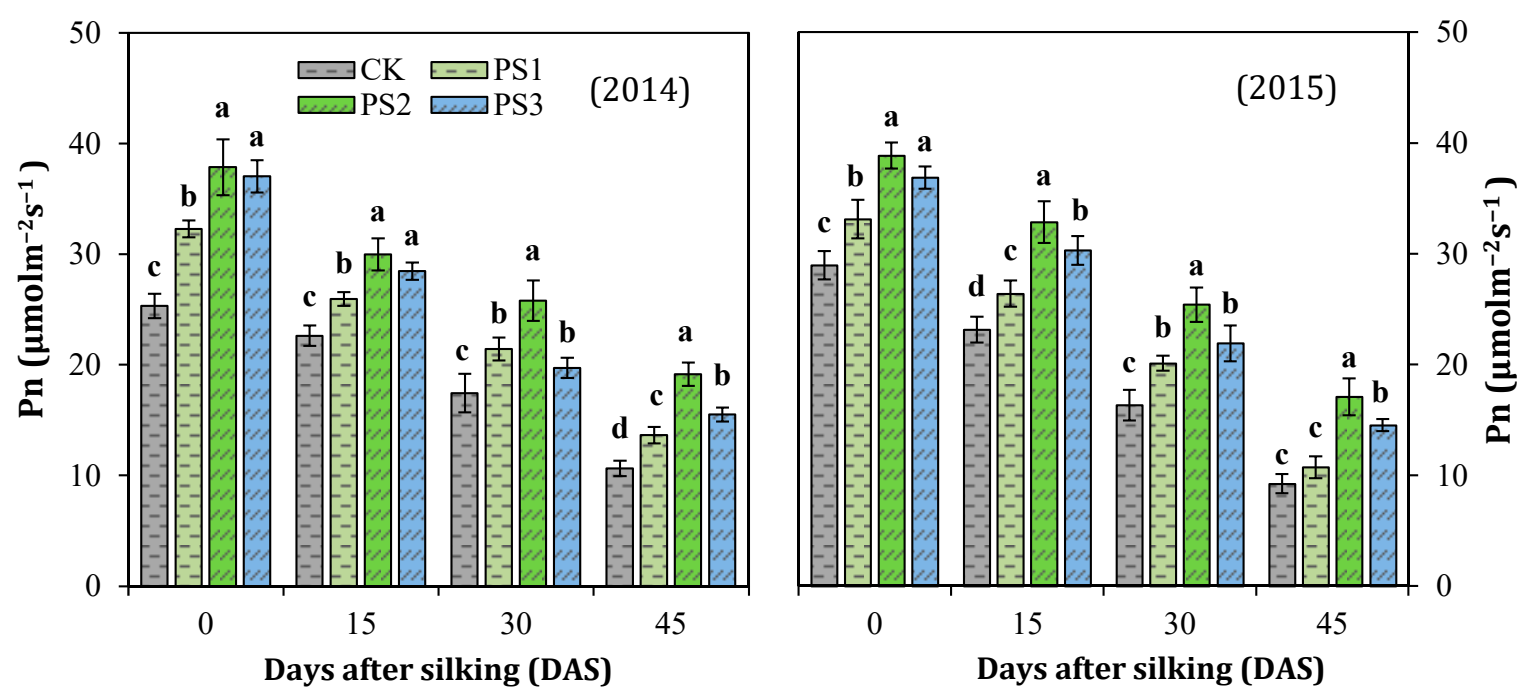

Figure 4. Effects of paclobutrazol treatments on net photosynthesis rate of maize during 2014 and 2015. Data are presented as mean \pm SD of three measurements. Different small letters on the bars indicate significant differences at $P<0.05$ (LSD test). The abbreviations of treatment names are the same as those described in Figure 2.

\subsection{Chlorophyll Fluorescence}

Paclobutrazol treatments, sampling times, and year exhibited significant effects on primary fluorescence (Fo) (Table 3). The value of Fo gradually increased with an increase in the days after silking. However, the paclobutrazol-treated plants exhibited a decline in the Fo values compared to control plants. The two years' (2014 and 2015) mean results showed that the Fo values of PS1, PS2, and PS3 treatments were decreased significantly by $21.5 \%, 40.6 \%$, and $28.8 \%$ at 0 DAS, $14.2 \%, 38.1 \%$, and $18.3 \%$ at 15 DAS, $20.0 \%, 34.8 \%$, and $19.2 \%$ at 30 DAS, $15.9 \%, 35.9 \%$, and $24.2 \%$ at 45 DAS, respectively (Figure 5A). 

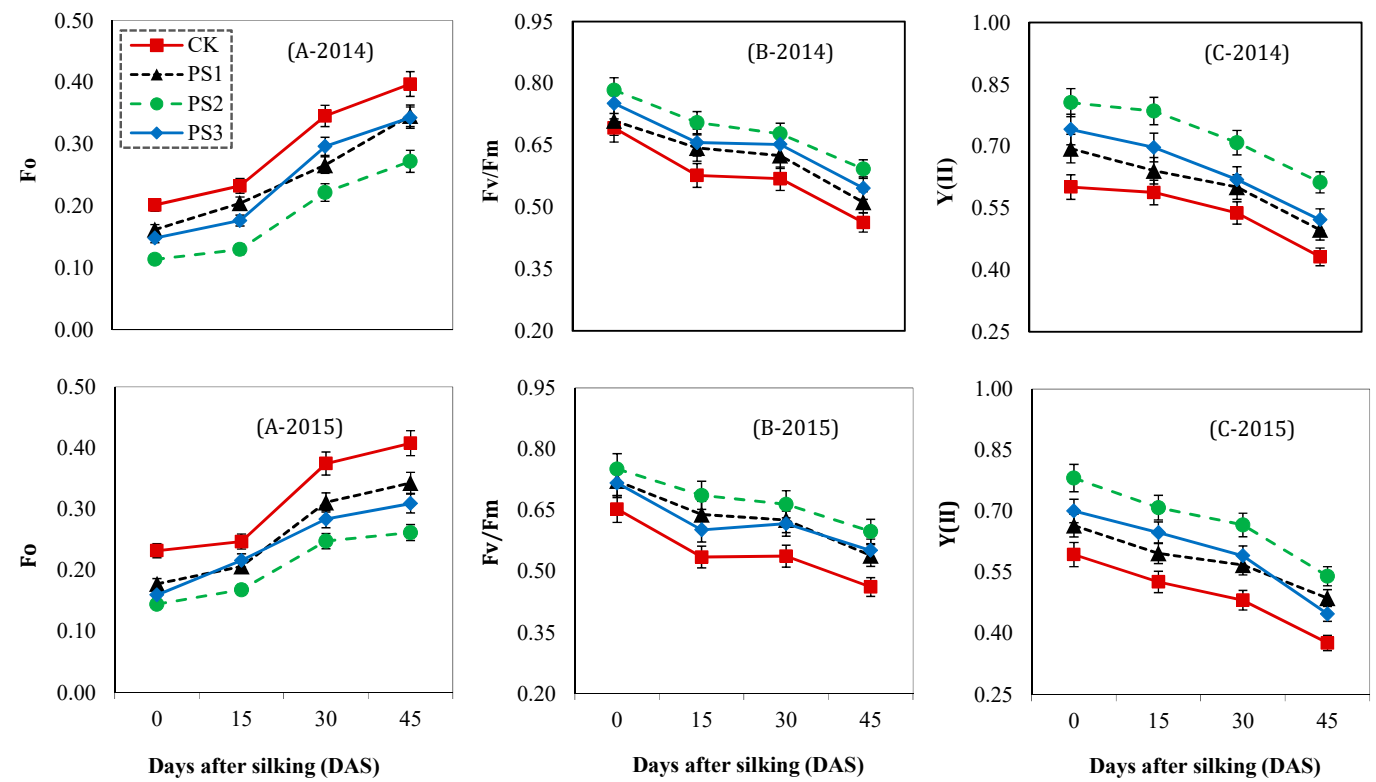

Figure 5. Effects of paclobutrazol treatments on (A) primary fluorescence, Fo (B) maximum quantum efficiency of PSII, Fv/Fm, and (C), actual quantum yield of PSII, Y(II), in maize during 2014 and 2015. Data are presented as mean \pm SD of three measurements. Different letters indicate significant differences at $P<0.05$ (LSD test). The abbreviations of treatment names are the same as those described in Figure 2.

Paclobutrazol treatments, sampling times, and year showed significant effects on the value of maximum quantum efficiency $(\mathrm{Fv} / \mathrm{Fm})$. The interaction of various factors was significant except for that of paclobutrazol, year, and sampling times $(\mathrm{Y} \times \mathrm{P} \times \mathrm{T})$ (Table 3). The $\mathrm{Fv} / \mathrm{Fm}$ values progressively declined with the advancement of days after silking (Figure 5B). Paclobutrazol treatments maintained relatively higher Fv/Fm values, among which PS2 treatment exhibited the most significant effect on enhancing $\mathrm{Fv} / \mathrm{Fm}$ values. The highest concentration of paclobutrazol treatment (PS3) showed an inhibitory effect and declines the Fv/Fm values compared to PS2, and the values were similar to that in PS1 treatment. When compared to control, the values of Fv/Fm in PS2 treatment was greater by $13.3 \%$ and $15.2 \%$ at 0 DAS, $22.3 \%$ and $18.4 \%$ at 15 DAS, $19.1 \%$ and $23.7 \%$ at 30 DAS, $28.0 \%$ and $29.6 \%$ at 45 DAS during 2014 and 2015, respectively (Figure 5B).

$Y($ II) was significantly affected by paclobutrazol treatments, sampling time, and year. Among the various interactions, only $\mathrm{Y} \times \mathrm{T}$ was significant (Table 3). $\mathrm{Y}$ (II) values showed a decreasing tendency from 0 to 45 DAS in all treatments (Figure 5C). However, paclobutrazol treatments increased the $Y$ (II) values, compared to control. The two years' (2014 and 2015) mean results portrayed that PS2 and PS3 treatments increased Y(II) values by $32.8 \%$ and $20.6 \%$ at 0 DAS, $34.1 \%$ and $20.8 \%$ at 15 DAS, $35.1 \%$ and $18.9 \%$ at 30 DAS, and $42.7 \%$ and $19.9 \%$ at 45 DAS during the two growing seasons, respectively, compared to control (Figure 5C).

\subsection{Activities of Antioxidant Enzymes}

The antioxidant enzymes' activities represent the anti-aging ability and have crucial roles in delaying the leaf senescence process in plants. Paclobutrazol treatments, sampling times, and year showed significant effects on SOD activity and the interactions among the various factors were also significant (Table 3). The SOD activity followed an increasing tendency from 0 to 15 DAS and thereafter a decreasing tendency up to 45 DAS in the years 2014 and 2015 (Figure 6A). The different paclobutrazol treatments enhanced SOD activity at varying degrees. From 0 to 15 DAS, the enzyme activity was significantly greater in PS2 and PS3 treatments; however, from 30 to 45 DAS, the enzyme activity was significantly declined in PS3 treatment than that in PS2 treatment. When compared to control, the two year mean SOD activity of PS1, PS2, and PS3 treatments displayed an increase of $6.2 \%, 14.4 \%$, and 
$12.4 \%$ at 0 DAS, $10.0 \%, 22.9 \%$, and $9.9 \%$ at 15 DAS, $11.3 \%, 29.1 \%$, and $21.0 \%$ at $30 \mathrm{DAS}, 16.7 \%, 38.6 \%$, and $28.1 \%$ at 45 DAS, respectively (Figure $6 \mathrm{~A}$ ).
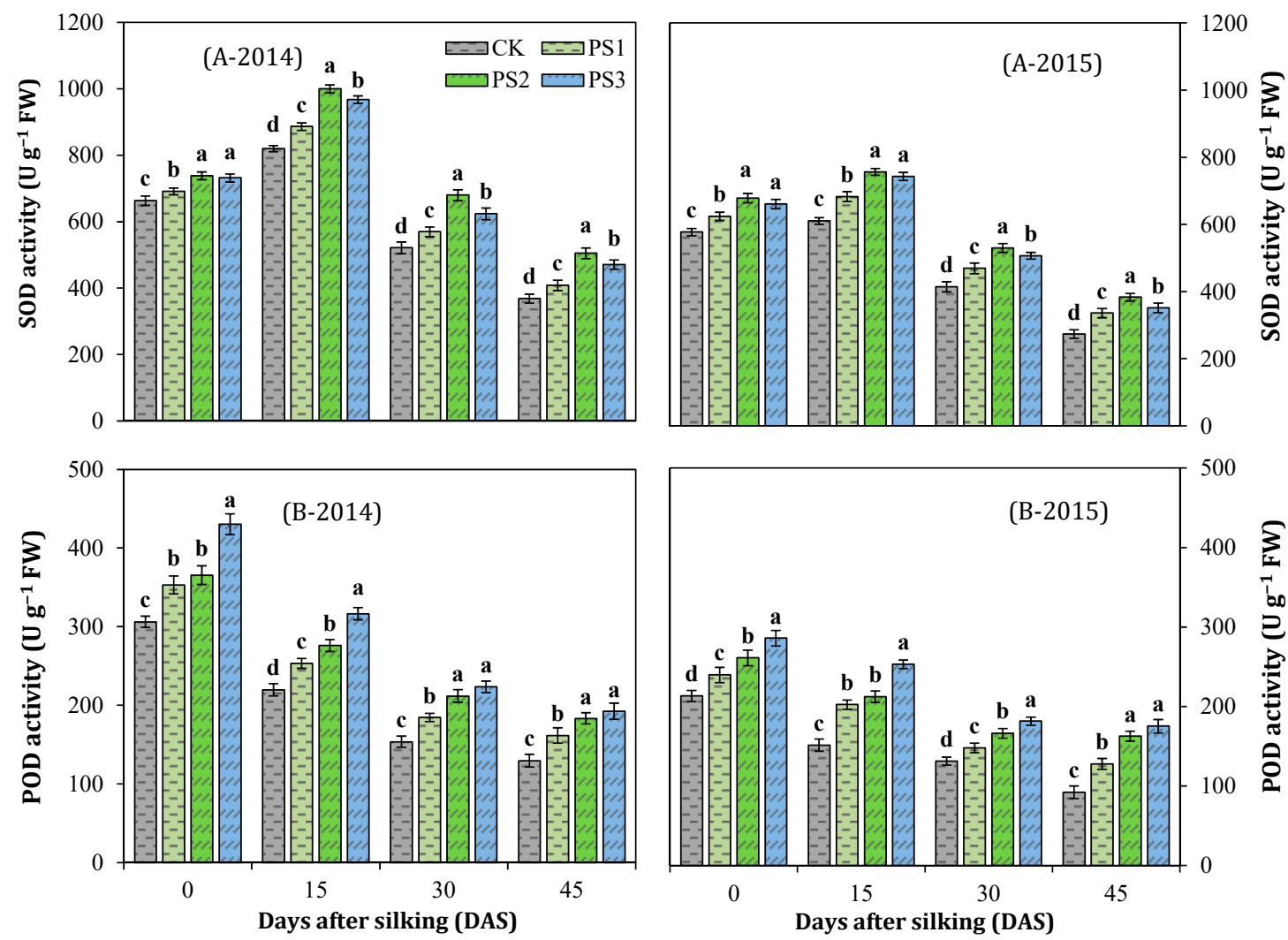

Figure 6. Effects of paclobutrazol treatments on (A) superoxide dismutase, SOD, and (B) peroxidase, POD, activity in maize leaves during 2014 and 2015. Data are presented as mean \pm SD of three measurements. Different small letters on the bars indicate significant differences at $P<0.05$ (LSD test). The abbreviations of treatment names are the same as those described in Figure 2.

Similarly, the paclobutrazol treatments, year and sampling times exhibited significant effects on POD activity. Among the various interactions, only $\mathrm{Y} \times \mathrm{P}$ was not significant (Table 3 ). The enzyme activity was greater (31.9\%) in 2014 than in 2015. In both years, the POD activity was maximal at 0 DAS and then considerably declined in all treatments with the progression of days after silking (Figure 6B). With an increase in the paclobutrazol treatment concentrations, POD activity was positively improved at all growth stages from 2014 to 2015. During the leaf senescence process, PS3 treatment exhibited the highest POD activity compared to other paclobutrazol treatments and the control (Figure 6B). The two years' mean (2014 and 2015) results portrayed that PS1, PS2, and PS3 treatment significantly increased the POD activity by $13.9 \%, 21.0 \%$, and $37.3 \%$ at 0 DAS, $24.5 \%, 33.0 \%$, and $55.7 \%$ at 15 DAS, $16.3 \%$, $32.2 \%$, and $41.9 \%$ at $30 \mathrm{DAS}, 31.8 \%, 59.2 \%$, and $69.5 \%$ at $45 \mathrm{DAS}$, compared with control, respectively.

The paclobutrazol treatments, year, and sampling times significantly affected CAT activity, and interactions among the various factors were also significant (Table 3). The CAT activity initially increased and exhibited single-peak curves at 15 DAS, and then gradually declined from 15 to 45 DAS from 2014 to 2015 (Figure 7A). Our results indicated that the CAT activity was significantly improved in paclobutrazol treatments compared with control treatment. At each stage, the enzyme activity linearly increased at a higher concentration of paclobutrazol, where the PS3 treatment exhibited the greatest CAT activity followed by the PS2 treatment. The two years' mean results portrayed that PS1, PS2, and PS3 treatments increased CAT activity by 16.2, 29.7, and 31.25 at 0 DAS, $22.4 \%, 25.6 \%$, and $32.6 \%$ at $15 \mathrm{DAS}, 23.8 \%, 45.0 \%$, and $50.3 \%$ at $30 \mathrm{DAS}, 37.6 \%, 70.6 \%$, and $72.7 \%$ at $45 \mathrm{DAS}$, compared to control, respectively (Figure 7A). 

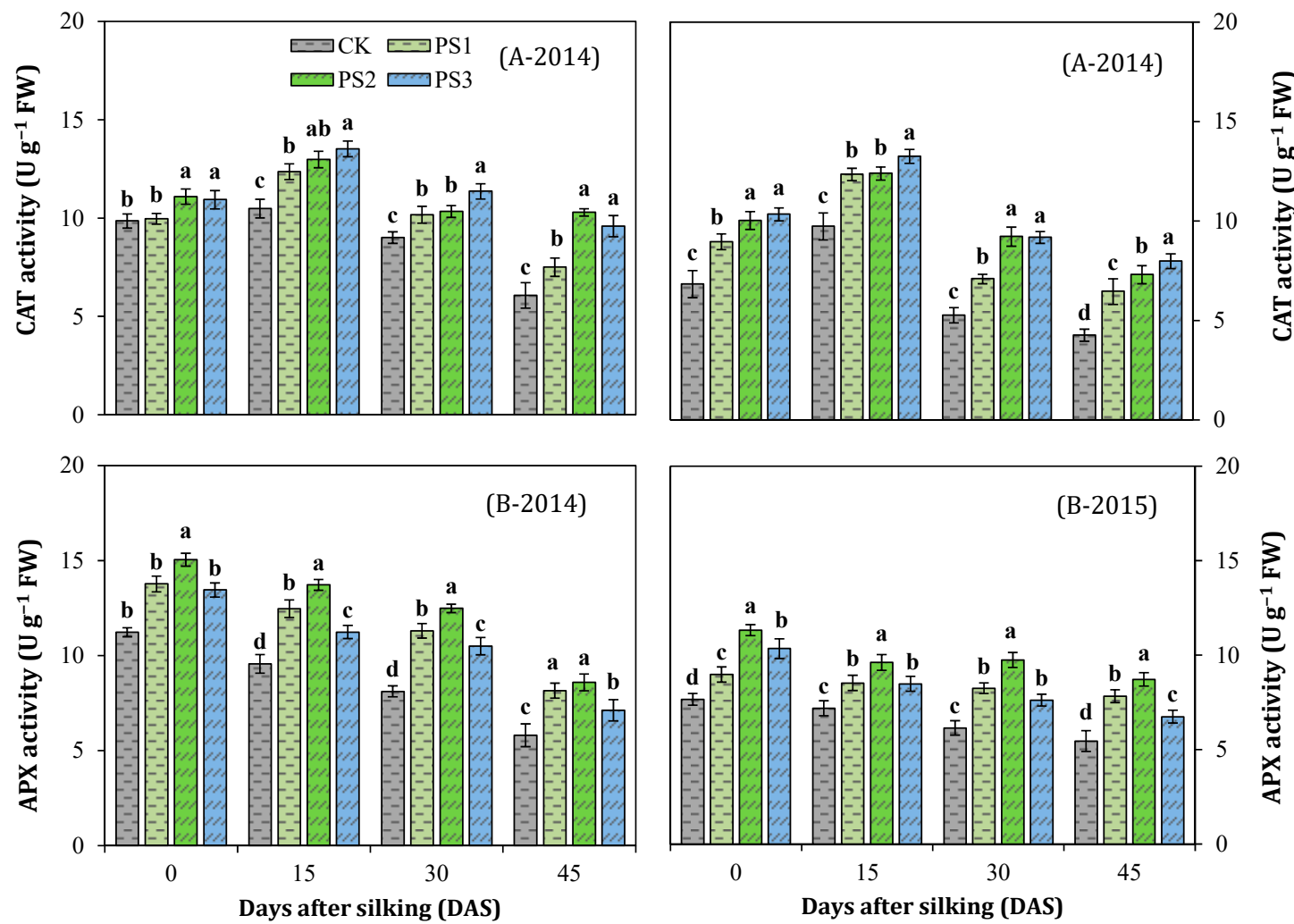

Figure 7. Effects of paclobutrazol treatments on (A) catalase, CAT, and (B) ascorbate peroxidase, APX, activity in maize leaves during 2014 and 2015. Data are presented as mean \pm SD of three measurements. Different small letters on the bars indicate significant differences at $P<0.05$ (LSD test). The abbreviations of treatment names are the same as those described in Figure 2.

The APX activity was also affected by paclobutrazol, year, and sampling times. All the interactions among the different factors were significant (Table 3). Unlike CAT, the APX activity followed a different trend and followed a gradually decreasing trend from 0 to 45 DAS. The various paclobutrazol treatments increased the APX activity but in a different way. The APX activity initially increased and then declined with the highest concentration of paclobutrazol at each stage, where the PS2 treatment resulted in higher APX activity compared to the rest of the treatments (Figure 7B). Unlike the other antioxidants (SOD, POD, CAT), the APX activity was dramatically declined in PS3 treatment and was even lower than that in PS1 treatment, particularly at the later growth stages of maize crop. Compared with the control, the two years' mean APX activity in PS2 treatment was increased by $40.9 \%, 28.7 \%$, $56.2 \%$, and $53.8 \%$ at $0,15,30$, and 45 DAS, respectively (Figure $7 \mathrm{~B}$ ).

\subsection{Reactive Oxygen Species (ROS) Accumulation and Lipid Peroxidation}

The accumulation of ROS results in degradation of the photosynthetic pigments with the progression of the leaf senescence process at the crop reproductive stage. Our results showed that $\mathrm{H}_{2} \mathrm{O}_{2}$ and $\mathrm{O}_{2}{ }^{-}$contents were significantly affected by paclobutrazol, year, and sampling times (Table 3 ). In both growing seasons, $\mathrm{H}_{2} \mathrm{O}_{2}$ and $\mathrm{O}_{2}{ }^{-}$contents showed a gradually increasing trend from 0 to 15 DAS and increased dramatically from 30 to 45 DAS with an increase in leaf senescence rate (Figure 8A,B). Paclobutrazol application treatments markedly reduced ROS accumulation and the best effects appeared in PS2-treated plants. Compared to untreated control plants, the two years' mean result showed that $\mathrm{H}_{2} \mathrm{O}_{2}$ and $\mathrm{O}_{2}{ }^{-}$contents of PS2-treated plants was lowered by $51.0 \%$ and $40.1 \%$ at 0 DAS, $45.0 \%$ and $42.0 \%$ at 15 DAS, $63.4 \%$ and $51.8 \%$ at 30 DAS, and $58.2 \%$ and $50.4 \%$ at 45 DAS, respectively (Figure $8 \mathrm{~A}, \mathrm{~B})$. 

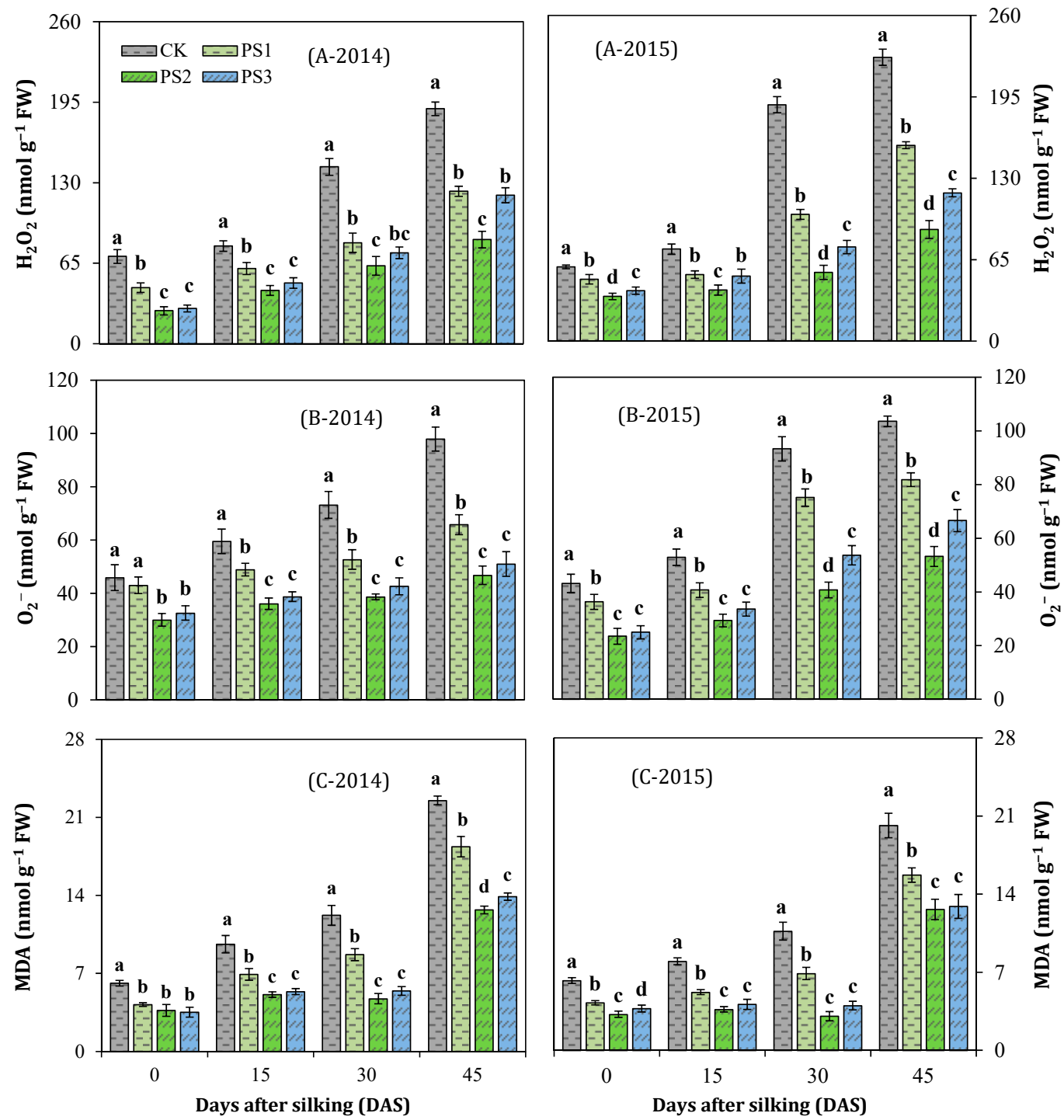

Figure 8. Effects of paclobutrazol treatments on (A) hydrogen peroxide, $\mathrm{H}_{2} \mathrm{O}_{2},($ B) superoxide radical, $\mathrm{O}_{2}{ }^{-}$, and (C) malondialdehyde, MDA, contents in maize leaves during 2014 and 2015. Data are presented as mean \pm SD of three measurements. Different small letters on the bars indicate significant differences at $P<0.05$ (LSD test). The abbreviations of treatment names are the same as those described in Figure 2.

Similar to ROS accumulation, the MDA contents were significantly affected by PGR, year, and sampling times. The interaction of year and sampling times $(\mathrm{Y} \times \mathrm{T})$ and paclobutrazol with sampling time $(\mathrm{P} \times \mathrm{T})$ were significant (Table 3). The MDA content tended to increase gradually with the progression of leaf senescence process during 2014-2015 (Figure 8C). However, the MDA contents were significantly lower in all of the paclobutrazol treatments over the control treatment. The two years' mean results depicted that the PS1, PS2, and PS3 treatments significantly reduced the MDA content by $31.5 \%, 44.1 \%$, and $41.3 \%$ at 0 DAS, $31.4 \%, 50.4 \%$, and $46.3 \%$ at 15 DAS, $32.2 \%, 66.3 \%$, and $59.0 \%$ at 30 DAS, and $20.2 \%, 40.5 \%$, and $37.1 \%$ at 45 DAS, respectively, compared with the control (Figure 8 C).

\subsection{Soluble Protein and Soluble Sugar}

Soluble protein contents were significantly affected by paclobutrazol treatments, year, and sampling times, but the interactions of $\mathrm{P} \times \mathrm{T}$ and $\mathrm{Y} \times \mathrm{P} \times \mathrm{T}$ were non-significant (Table 3). The soluble protein contents slightly increased from 0 to $15 \mathrm{DAS}$ and thereafter gradually declined from 15 to $45 \mathrm{DAS}$ 
in all treatments (Figure 9A). However, this decline was partially mediated by paclobutrazol treatments at varying degrees. From 0 to 15 DAS, plants treated with a high concentration of paclobutrazol treatments (PS2 and PS3) maintained greater protein content, but the protein content was greatly inhibited in PS3 treatment from 30 to 45 DAS, compared to PS2 treatment. The mean based on two years' results showed that PS1, PS2, and PS3 treatments increased soluble protein contents by $13.3 \%$, $24.5 \%$, and $21.3 \%$ at 0 DAS, $11.6 \%, 24.7 \%$, and $21.2 \%$ at 15 DAS, $13.7 \%, 31.8 \%$, and $21.7 \%$ at 30 DAS, and $26.1 \%, 61.7 \%$, and $44.3 \%$ at $45 \mathrm{DAS}$, respectively, compared with the control treatment (Figure $9 \mathrm{~A}$ ).
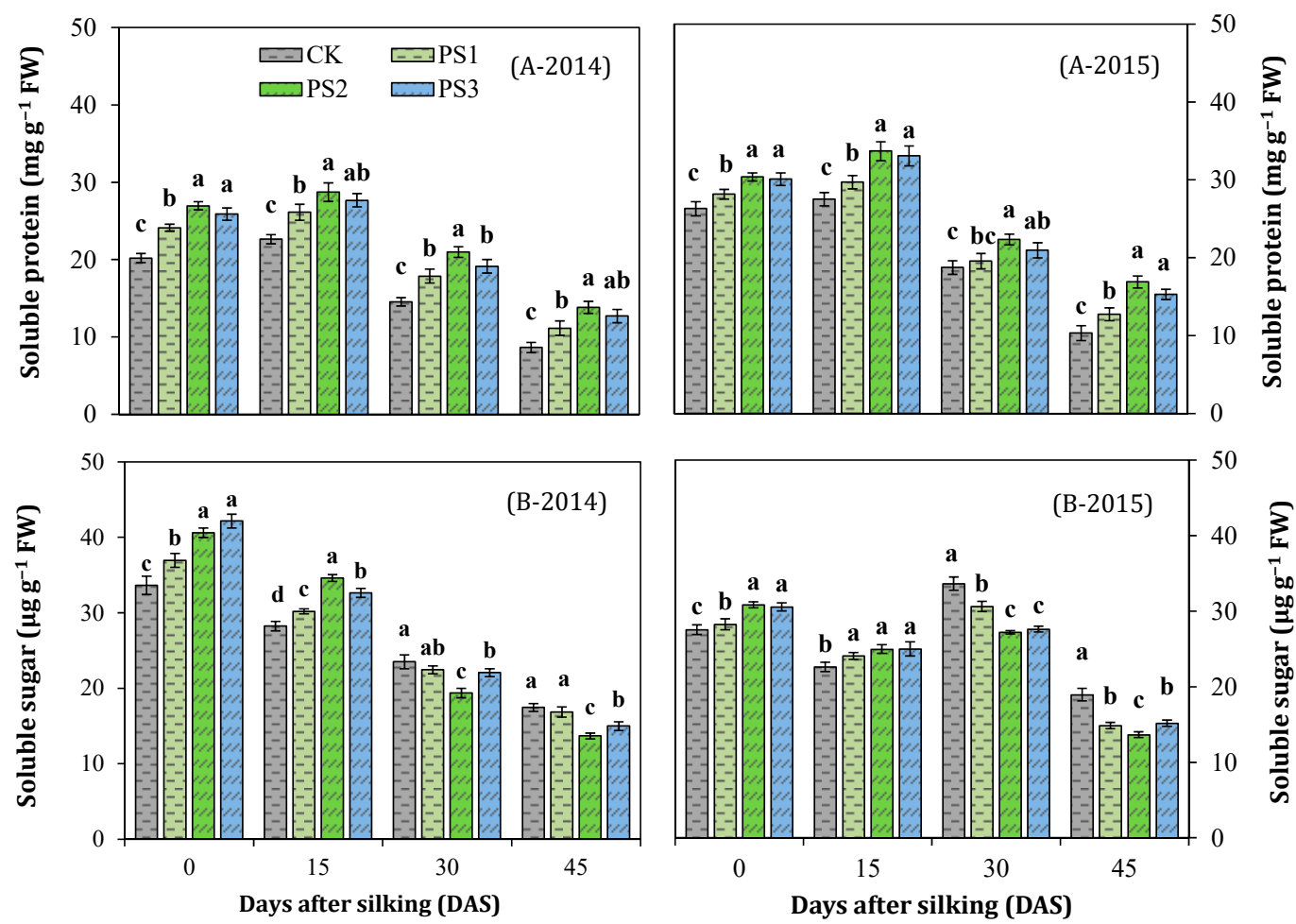

Figure 9. Effects of paclobutrazol treatments on (A) soluble protein and (B) soluble sugar contents in maize leaves during 2014 and 2015. Data are presented as mean \pm SD of three measurements. Different small letters on the bars indicate significant differences at $P<0.05$ (LSD test). The abbreviations of treatment names are the same as those described in Figure 2.

Unlike the soluble protein, soluble sugars followed a totally different trend. The soluble sugar contents gradually declined with the increase in days after silking and leaf senescence rate in all treatments (Figure 9B). From 0 to 15 DAS, soluble sugar contents were significantly greater in paclobutrazol application treatments than control but were lower than control after 30 to 45 DAS during both growing seasons. The decreasing level of soluble sugar content was greater in PS2 treatment compared to control and other treatments (Figure 9B).

\subsection{Correlation Analysis}

Pearson's correlation analysis revealed a significant positive correlation of leaf senescence with $\mathrm{H}_{2} \mathrm{O}_{2}, \mathrm{O}_{2}^{-}$, and MDA contents (Table 4). A negative correlation was detected for leaf senescence, ROS, and MDA contents with that of antioxidant enzymes, chlorophyll content, net photosynthetic rate, chlorophyll fluorescence, and soluble protein (Table 4). Moreover, chlorophyll content, net photosynthetic rate, protein content, and chlorophyll fluorescence were significantly and positively correlated with grain yield (Table 4). 
Table 4. Relationships between photosynthetic pigments, leaf senescence, soluble protein, net photosynthetic rate, chlorophyll fluorescence, antioxidant enzymes, reactive oxygen species, and grain yield.

\begin{tabular}{|c|c|c|c|c|c|c|c|c|c|c|c|c|c|c|}
\hline & Chl & Car & LS & SOD & POD & CAT & APX & $\mathrm{H}_{2} \mathrm{O}_{2}$ & $\mathrm{O}_{2}^{-}$ & MDA & Pn & Fv/Fm & $\mathrm{Y}(\mathrm{II})$ & SP \\
\hline Car & $0.861^{* *}$ & & & & & & & & & & & & & \\
\hline LS & $-0.962^{* *}$ & $-0.948^{* *}$ & & & & & & & & & & & & \\
\hline SOD & $0.968^{* *}$ & $0.931^{* *}$ & $-0.989^{* *}$ & & & & & & & & & & & \\
\hline POD & $0.752^{* *}$ & $0.973^{* *}$ & $-0.868^{* *}$ & $0.863^{* *}$ & & & & & & & & & & \\
\hline CAT & $0.870^{* *}$ & $0.988^{* *}$ & $-0.945^{* *}$ & $0.922^{* *}$ & $0.946^{* *}$ & & & & & & & & & \\
\hline APX & $0.959^{* *}$ & 0.750 ** & $-0.880^{* *}$ & $0.870^{* *}$ & $0.608^{*}$ & $0.774^{*}$ & & & & & & & & \\
\hline $\mathrm{H}_{2} \mathrm{O}_{2}$ & $-0.973^{* *}$ & $-0.932^{* *}$ & $0.977^{* *}$ & $-0.970^{* *}$ & $-0.849^{* *}$ & $-0.936^{* *}$ & $-0.930^{* *}$ & & & & & & & \\
\hline $\mathrm{O}_{2}^{-}$ & $-0.966^{* *}$ & $-0.952^{* *}$ & $0.996^{* *}$ & $-0.995^{* *}$ & $-0.882^{* *}$ & $-0.947^{* *}$ & $-0.879^{* *}$ & $0.980^{* *}$ & & & & & & \\
\hline MDA & $-0.948^{* *}$ & $-0.963^{* *}$ & $0.984^{* *}$ & $-0.985^{* *}$ & $-0.912^{* *}$ & $-0.952^{* *}$ & $-0.863^{* *}$ & $0.982^{* *}$ & $0.992^{* *}$ & & & & & \\
\hline Pn & $0.983^{* *}$ & $0.898^{* *}$ & $-0.985^{* *}$ & $0.985^{* *}$ & $0.806^{* *}$ & $0.904^{* *}$ & $0.911^{* *}$ & $-0.974^{* *}$ & $-0.985^{* *}$ & $-0.965^{* *}$ & & & & \\
\hline Fv/Fm & $0.987^{* *}$ & $0.862^{* *}$ & $-0.958^{* *}$ & $0.953^{* *}$ & $0.746^{* *}$ & $0.883^{* *}$ & $0.964^{* *}$ & $-0.980^{* *}$ & $-0.956^{* *}$ & $-0.940^{* *}$ & $0.977^{* *}$ & & & \\
\hline $\mathrm{Y}(\mathrm{II})$ & $0.986^{* *}$ & $0.823^{* *}$ & $-0.935^{* *}$ & $0.951^{* *}$ & $0.704^{*}$ & $0.843^{* *}$ & $0.934^{* *}$ & $-0.938^{* *}$ & $-0.939^{* *}$ & $-0.909^{* *}$ & $0.966^{* *}$ & $0.972^{* *}$ & & \\
\hline SP & $0.971^{* *}$ & $0.940^{* *}$ & $-0.988^{* *}$ & $0.985^{* *}$ & $0.853^{* *}$ & $0.934^{* *}$ & $0.887^{* *}$ & $-0.973^{* *}$ & $-0.988^{* *}$ & $-0.973^{* *}$ & $0.976^{* *}$ & $0.960^{* *}$ & $0.955^{* *}$ & \\
\hline Yield & $0.961^{* *}$ & $0.886^{* *}$ & $-0.974^{* *}$ & $0.980^{* *}$ & $0.805^{* *}$ & $0.893^{* *}$ & $0.869^{* *}$ & $-0.951^{* *}$ & $-0.973^{* *}$ & $-0.951^{* *}$ & $0.993^{* *}$ & $0.955^{* *}$ & $0.952^{* *}$ & $0.959^{* *}$ \\
\hline
\end{tabular}

Chl, chlorophyll; Car, carotenoid; LS, leaf senescence rate; SOD, superoxide dismutase; POD, peroxidase; CAT, catalase; APX, ascorbate peroxidase; $\mathrm{H}_{2} \mathrm{O}_{2}$, hydrogen peroxide; $\mathrm{O}_{2}{ }^{-}$, superoxide radical; MDA, malondialdehyde; Pn, net photosynthetic rate; Fv/Fm, maximum quantum efficiency of PSII; Y(II), actual quantum yield of PSII; SP, soluble protein. ${ }^{* *}$ Correlation is significant at the 0.01 level; ${ }^{*}$ correlation is significant at the 0.05 level. 


\section{Discussion}

In the semiarid regions, water-deficit condition often triggers the early onset of premature leaves senescence due to the degradation of chlorophyll contents, which along with protein degradation greatly declines the photosynthetic capacity [8,34]. Examining the variation in chlorophyll and carotenoid concentration and alteration in photosynthesis rate has been reported as the most important indicators of leaf's physiological activities and an instinctive way for studying the leaf senescence [16]. Results of our present study clearly indicated that the leaf senescence rate progressively increased in maize plants with an increase in days after silking. The rate of leaf senescence was comparatively higher in 2015 than 2014, perhaps due to a drier season in 2015. The correlation analysis indicated that increases in leaf senescence were positively correlated with the increase in degradation of chlorophyll and carotenoid contents in maize leaves. This decrease in chlorophyll and carotenoid contents can be linked with greater lipid peroxidation in the chloroplast membranes during the leaf senescence process, which is in agreement with the previous report [14]. Previously, some studies have reported that the application of plant growth regulators (PGRs) has major effects on improving plant growth and development $[5,6,8,27]$. Our results also depicted that paclobutrazol application treatments evidently delayed the leaf senescence process and maintained higher chlorophyll contents in maize leaves, compared with the untreated control plants. Previously, Fletcher et al. [35] proposed that the inhibition of lipid peroxidation is one of the possible mechanisms associated with the anti-senescence effects of triazoles. In addition, the leaves of paclobutrazol-treated maize plants appeared to be dark green in color than the control plants. This dark green color was either due to the enhanced synthesis of chlorophyll or the presence of more chloroplasts per unit leaf area of treated leaves, which is in agreement with the previous studies of Berova et al. [36], Khalil and Rahman [37], and Tekalign [38]. The increase in chlorophyll content with paclobutrazol treatments can be attributed to increased synthesis of cytokinins (CK), which stimulates biosynthesis of chlorophyll and prevents its degradation by delaying senescence and physiological maturity in treated plants [35,38,39]. Another possible explanation is that triazoles inhibit the cycling of geranylgeranyl pyrophosphate (GGPP, a diterpene precursor associated with biosynthesis of chlorophyll, carotenoids, and tocopherols) into ent-Kaurene along the gibberellin biosynthesis pathway $[35,40]$. Hence, paclobutrazol application treatments may result in more conversion of GGPP into diterpene rather than to ent-kaurene, and increase chlorophyll and carotenoids contents. The protective role of paclobutrazol on delaying the degradation of chlorophyll and leaf senescence was also verified in Daucus carota [39], wheat [41], rice [42], and pomegranate [43] under unfavorable environmental conditions. In a previous study, exogenous application of uniconazole (with functions similar to paclobutrazol) to maize plants has been reported to maintain higher chlorophyll contents and delayed leaf senescence in maize by upregulating the activities of antioxidants [5].

The down-regulation of photosynthetic capacity during the senescence has been widely documented in the previous studies $[5,7,12,16]$. In our present study, the net photosynthetic rate of maize plants declined gradually with the increase in days after silking in all treatments. This decrease in photosynthetic rate was linearly correlated with the increase in leaf senescence rate and decrease in chlorophyll contents in maize leaves. Paclobutrazol application treatments, however, maintained significantly higher photosynthetic rates during both growing seasons, with the best effects observed in PS2 treatment compared to control and other paclobutrazol treatments. The increase in photosynthetic efficiency with paclobutrazol could be linked with the enhanced chlorophyll pigments and delayed leaf senescence at later growth stages in the treated maize plants, which is in agreement with the previous reports of Gopi et al. [39], Bora et al. [44], and Wang et al. [45]. In support of our findings, previous studies have indicated that exogenous application of various triazole PGRs significantly improved the net photosynthetic rate in Raphanus sativus [46], Amorphophallus campanulatus [47], and Catharanthus roseus [48]. Remarkably, the application of paclobutrazol at a high concentration (PS3 treatment) showed inhibitory effects on plant growth and declined the net photosynthetic rate compared to PS2 treatment. Previously, reports of Yim et al. [49] and Navarro et al. [50] showed that although 
paclobutrazol application increased chlorophyll contents in rice and strawberry plants, the impact was minimal on photosynthetic efficiency. Since paclobutrazol is an anti-gibberellic growth inhibitor, the higher concentration might result in a critical reduction of plant growth and development that would result in reduced photosynthetic rate [20]. Previous literature showed that the effects of triazoles might either be stimulatory or inhibitory, depending on the crop, as well as the concentration of the growth regulator used [35]. Therefore, identification and application of an optimum concentration for PGRs are imperative.

Measurement of chlorophyll fluorescence has become one of the most powerful and widely used means for obtaining information about the state of PSII and provides insight into the plant's ability to tolerate environmental conditions that can damage photosynthetic apparatus and decrease yield [7,16]. Gilley and Fletcher [51] have reported that chlorophyll fluorescence ratio (Fv/Fm) is strongly correlated with photosynthetic efficiency and a decline in this rate is a remarkable characteristic of photosynthesis inhibition. Chlorophyll fluorescence transiently increases in the newly expanding leaves and decrease significantly with leaf senescence [52]. The results of our present study showed that PSII efficiency declined progressively with the advancement of leaf senescence in all treatments. The decrease in Fv/Fm and PSII values was more rapidly in control than did in the paclobutrazol treatments. Among all the treatments, PS2 was found to consistently maintain the maximum efficiency of PSII photochemistry of maize plants grown under semiarid field conditions. Under optimum growth conditions, the $\mathrm{Fv} / \mathrm{Fm}$ is proposed to be around 0.8 [8], and the most adjacent values were observed in paclobutrazol-treated plants, but the values were markedly lower in the untreated control plants. Significant and positive correlations were detected for the increase in grain yield with increased efficiency of PSII and Fv/Fm values. The increased chlorophyll fluorescence in paclobutrazol treatments is dedicated due to its positive effects on increasing chlorophyll contents that can increase the rate of absorption and transmission of electrons, and hence, optimizing the PSII reaction and enhancing photosynthetic capacity. Our results are in agreement with the previous studies, which reported increased energy transformation efficiency in the PSII reaction center and photosynthetic capacity in PGRs treatments $[7,8,16,36]$.

The ROS-triggered lipid peroxidation is an intrinsic characteristic of leaf senescence that causes membrane permeability and damages to the integrity of cell membrane structure $[15,53]$. Malondialdehyde (MDA), a byproduct of lipid peroxidation is widely considered an important stress marker [32]. Our results indicated a continuous increase in endogenous levels of MDA contents in maize leaves with the advancement of leaves senescence after the silking stage. An increase in MDA contents with an increase in leaf senescence from flowering to dough stage has been reported in maize crops [5,8]. Wu and Von Tiedemann [14] indicated that the acceleration in the senescence rate is always positively associated with the increase of MDA contents. However, leaves of paclobutrazol-treated maize plants had lower MDA content than those in untreated control plants. The decreased MDA content owing to paclobutrazol treatments may be related to delayed senescence and high antioxidants' activities, which plays a vital role in maintaining ROS homeostasis in cells and protect cells from oxidative damages. These findings are in agreement with the previous studies, which indicated that triazole treatments can reduce the oxidative injury to the plants membrane by inhibiting MDA accumulation, associated with enhanced antioxidants' activities $[8,19,35,36]$.

The onset and progression of leaf senescence are widely considered to be associated with and driven by the excessive accumulation of ROS, which in high levels cause damage to lipids, proteins, and DNA, resulting in cellular death $[15,54]$. To eliminate the negative effects of ROS, specifically $\mathrm{O}_{2}{ }^{-}$, on the cell, the plants require an effective antioxidant system $[8,55]$. SOD is the primary antioxidant of the plant defense system that effectively catalyzes toxic $\mathrm{O}_{2}{ }^{-}$to $\mathrm{H}_{2} \mathrm{O}_{2}$ [56]. In our present study, the SOD activity initially increased from 0 to 15 DAS and then subsequently decreased from 15 to 45 DAS, while the $\mathrm{O}_{2}{ }^{-}$exhibited a progressively increasing trend from 0 to 45 DAS during the leaf senescence. This increase in $\mathrm{O}_{2}{ }^{-}$content with the progression of senescence was possibly due to a weak scavenging ability and reduced SOD activity, which is in agreement with the previous reports of 
Dhindsa et al. [15] and Wang et al. [8]. In wheat and rice leaves, senescence was positively correlated with the increase in levels of ROS and the decrease in SOD activity $[9,14]$. Dhindsa et al. [15] and Wang et al [9] proposed that the activity of SOD and $\mathrm{O}_{2}{ }^{-}$levels in leaves reflects the leaf senescent status. Our results portrayed that paclobutrazol treatments maintained significantly lower $\mathrm{O}_{2}{ }^{-}$content during the leaf senescence process of maize, which was attributed to enhanced SOD activity. The possible explanation is that higher SOD activities facilitated the conversion of $\mathrm{O}^{2-}$ to $\mathrm{H}_{2} \mathrm{O}_{2}$ and decreased the formation of hydroxyl radicals, at the same time $\mathrm{O}^{2-}$ was kept at lower concentrations [56]. Similar results have been demonstrated in previous experiments where PGRs application resulted in enhanced SOD activity that effectively detoxified $\mathrm{O}_{2}{ }^{-}$into $\mathrm{H}_{2} \mathrm{O}_{2}$ in wheat and maize $[5,8,14]$ and apple [16].

$\mathrm{H}_{2} \mathrm{O}_{2}$ is a resultant product of SOD activity and once it's formed, plants need an efficient enzymatic system to reduce it, since high levels of $\mathrm{H}_{2} \mathrm{O}_{2}$ could negatively affect the redox homeostasis $[19,57]$. The POD, APX, and CAT are the major antioxidants of the plant's defense systems that are associated with $\mathrm{H}_{2} \mathrm{O}_{2}$ detoxification [56]. The elevated activities of these antioxidants are positively correlated with enhanced tolerance of plants under unfavorable environmental conditions [53]. Results from our present study showed that CAT activity primarily increased from 0 to 15 DAS and later substantially declined; while, POD and APX activity continuously decreased with the progression in leaf senescence during both years. In addition, distinctly higher levels of $\mathrm{H}_{2} \mathrm{O}_{2}$ in maize leaves were detected and the higher $\mathrm{H}_{2} \mathrm{O}_{2}$ level was greatly stage-dependent, of which substantial rise occurred at later stages of the leaf senescence process. This corresponds with the findings of Wu and Von Tiedemann [14] and Wang et al. [8] that ROS contents gradually increased with an increase in days after flowering in wheat and maize. Wang et al. [8] and Ahmad et al. [5] also reported a similar trend of the antioxidants enzyme activities in their studies. Notably, our results indicated that the difference for these antioxidants was significant between the paclobutrazol application treatments and the control. These enzyme activities were markedly upregulated in paclobutrazol-treated plants at later growth stages of maize that significantly delayed and decreased the production of $\mathrm{H}_{2} \mathrm{O}_{2}$ over that of control treatment. The increases in activities of POD, CAT, and APX enzymes may have resulted from enhanced energy intercepted by the photosynthetic pigments. The upregulated antioxidant activities in leaves of stressed plants may be an adaptation intended to eliminate the stress-induced overproduced $\mathrm{H}_{2} \mathrm{O}_{2}$ [57]. Our correlation analysis showed a significant and negative relation between $\mathrm{H}_{2} \mathrm{O}_{2}$ levels and the activities of antioxidants. The protective roles of POD, APX, and CAT against oxidative burst have also been reported in paclobutrazol-treated barley [58], quinoa [19] C. roseus [26], and Chinese bayberry [59] under various environmental stress conditions. Our findings are also similar to the previous reports in which triazole treatments increased the activities of antioxidant enzymes and delayed the leaf senescence rate in different crops $[5,14,60]$. Similarly, Wang et al. [9] showed that the increased rate of ROS generation and the decreased activities of SOD, CAT, and APX in the leaves are strongly responsible for the accelerated leaf senescence in rice. Based on our results, we, therefore, infer that leaf longevity in paclobutrazol treatments was closely related to the enhanced activities of antioxidant enzymes that promoted scavenging of oxygen radicals, as evident by attenuated $\mathrm{H}_{2} \mathrm{O}_{2}$ and $\mathrm{O}_{2}$ levels in paclobutrazol-treated maize plants.

Soluble sugars and proteins can assist as osmotic regulators to stabilize membranes and to lower leaf water potentials [19]. Reddy et al. [61] reported that higher accumulations of these osmolytes are positively correlated with enhanced stress tolerance of plants and reduced photo-damages in the thylakoid membranes. In the present study, soluble protein showed an increasing trend from 0 to 15 DAS and a decreasing trend after that in all treatments. The paclobutrazol application treatments resulted in increased soluble protein contents and slowed its degradation during the senescence process, suggesting its potential role in increasing crop yield. Some previous studies have reported that induced accumulation of osmolytes by triazoles application facilitated maintenance of cell turgor, osmotic adjustment, and protection of cell structures in maize plants that lead to improvement in stress tolerance in various crops $[27,39,53,62]$. Paclobutrazol application has been known to enhance soluble protein contents in D. carota [39], white yam [62], and quinoa [19] under stress conditions. On the 
other hand, soluble sugar content exhibited a gradually decreasing trend with the increase in days after silking. From 0 to 15 DAS, soluble sugar contents were significantly greater in paclobutrazol application treatments than control, but were lower than control after 30 to 45 DAS during both growing seasons. The decrease of soluble sugars in paclobutrazol treatments at later growth stages is possibly due to the enhanced transportation of soluble sugar from leaves to kernels at the grain filling stage, which is in agreement with the previous study of Wang et al. [8].

Furthermore, in our study, paclobutrazol treatments expressively improved maize grain yield over that of untreated control treatment in both years. The increase in grain yield was mainly associated with greater TKW and higher kernel number per ear. The increase in TKW and kernel numbers may be linked with the enhanced chlorophyll contents, photosynthetic capacity, antioxidant defense system, and anti-aging capacity of paclobutrazol-treated maize, resulting in increased dry matter accumulation rate, and hence grain yield. The correlation analysis also depicted a significant positive correlation of grain yield with that of chlorophyll contents, photosynthesis rate, and antioxidant system, while negatively correlated with leaf senescence rate in maize crop. A previous study concluded a close link between the grain yield and the duration of green leaf area in wheat and this relation was greatly affected by the decrease in leaf viability during senescence [11]. Exogenous application of gibberellin-inhibitors such as uniconazole and paclobutrazol is known to reduce excessive vegetative growth, redirecting the assimilates to the plant's reproductive parts instead to the vegetative parts that in turn may enhance grain yield [25,40,63]. Moreover, Wang et al. [5,8] and Ahmad et al. [5] reported that a suitable application of triazole could delay the leaf senescence, improve the photosynthetic capacity, promote the grain filling and increase the grain yield of maize and wheat. It is pertinent to mention that the application of PS3 treatment resulted in lower grain yield compared with PS2 treatment during both growing seasons, which was attributed to the decrease in Kernels number ear ${ }^{-1}$, and thousand kernel weight. A possible explanation is that paclobutrazol is an anti-gibberellic PGR and its application at high concentration can result in significant reduction of vegetative growth and plant height (data not shown), that may result in reduction of photosynthetic capacity of a shorter canopy and hence in lower grain yield, which is agreement with the previous studies [20,25]. Wang et al. [22] and Ahmad et al. [5] also reported that a high concentration of triazole PGRs has an inhibitory effect on vegetative growth of buckwheat and wheat that resulted in lower grain yield.

\section{Conclusions}

Our results showed that an optimum concentration of paclobutrazol $\left(300 \mathrm{mg} \mathrm{L}^{-1}\right)$ can improve leaf longevity by delaying the leaf senescence rate associated with lower accumulation of ROS and MDA content in treated plants. Paclobutrazol treatments reduced the senescence-associated oxidative stress and lipid peroxidation by upregulating the activities of enzymatic antioxidants, improving the antioxidant defense system, which helped in sustaining plant growth. Furthermore, the anti-senescence regulatory effects of paclobutrazol enhanced the amounts of chlorophyll contents, net photosynthetic rate, and PSII efficiency, which resulted in improved ear characteristics and increased maize grain yield in both seasons. The positive influence of paclobutrazol on yield improvements of maize in the semiarid region offers new insights for its use in agriculture and also enhancing plant tolerances to adverse growing conditions.

Author Contributions: Conceptualization, M.K., W.G., and Q.H.; methodology, M.K., S.A., and I.A.; formal analysis, I.H. and X.M.; investigation, M.K., S.A., I.A., X.Z.; resources, W.G. and Q.H.; data curation, M.K., I.A., and R.D.; writing-original draft preparation, M.K. and S.A.; writing-review and editing, P.X., T.J., and M.U.; supervision, W.G. and Q.H. All authors have read and agreed to the published version of the manuscript.

Funding: The present study was financially supported by funding from High Technology Research and Development Program of China (863 Program, No.2013AA102902), the special fund for Agro-scientific Research in the Public Interest (201303104), Science and Technology Planning Project of Guangdong Province, China (2015B020237007, 2017A090905043, 2017B020203002, 2017B020233002, 2017B090907012), Dean project funding of the Guangdong Academy of Agricultural Sciences, China (201815B), and the 111 Project of Chinese Education Ministry (B12007). 
Conflicts of Interest: The authors declare no conflict of interest.

\section{References}

1. Xu, C.; Gao, Y.; Tian, B.; Ren, J.; Meng, Q.; Wang, P. Effects of EDAH, a novel plant growth regulator, on mechanical strength, stalk vascular bundles and grain yield of summer maize at high densities. Field Crops Res. 2017, 200, 71-79. [CrossRef]

2. Waqas, M.A.; Khan, I.; Akhter, M.J.; Noor, M.A.; Ashraf, U. Exogenous application of plant growth regulators (PGRs) induces chilling tolerance in short-duration hybrid maize. Env. Sci. Pollut. Res. 2017, 24, 11459-11471. [CrossRef] [PubMed]

3. Deng, X.P.; Shan, L.; Zhang, H.P.; Turner, N.C. Improving agricultural water use efficiency in arid and semiarid areas of China. Agric. Water Manag. 2006, 80, 23-40. [CrossRef]

4. Anjum, S.A.; Wang, L.C.; Farooq, M.; Hussain, M.; Xue, L.L.; Zou, C.M. Brassinolide application improves the drought tolerance in maize through modulation of enzymatic antioxidants and leaf gas exchange. $J$. Agron. Crop Sci. 2011, 197, 177-185. [CrossRef]

5. Ahmad, I.; Kamran, M.; Su, W.; Haiqi, W.; Ali, S.; Bilegjargal, B.; Ahmad, S.; Liu, T.; Cai, T.; Han, Q. Application of uniconazole improves photosynthetic efficiency of maize by enhancing the antioxidant defense mechanism and delaying leaf senescence in semiarid regions. J. Plant Growth Regul. 2019, 38, 855-869. [CrossRef]

6. Gao, Z.; Liang, X.G.; Zhang, L.; Lin, S.; Zhao, X.; Zhou, L.L.; Shen, S.; Zhou, S.L. Spraying exogenous 6-benzyladenine and brassinolide at tasseling increases maize yield by enhancing source and sink capacity. Field Crops Res. 2017, 211, 1-9. [CrossRef]

7. Ajigboye, O.O.; Murchie, E.; Ray, R.V. Foliar application of isopyrazam and epoxiconazole improves photosystem II efficiency, biomass and yield in winter wheat. Pestic. Biochem. Physiol. 2014, 114, 52-60. [CrossRef]

8. Wang, Y.; Wanrong, G.; Tenglong, X.; Lijie, L.; Yang, S.; He, Z.; Jing, L.; Shi, W. Mixed compound of DCPTA and CCC increases maize yield by improving plant morphology and up-regulating photosynthetic capacity and antioxidants. Plos ONE 2016, 11, e0149404. [CrossRef]

9. Wang, F.; Liu, J.; Zhou, L.; Pan, G.; Li, Z.; Zaidi, S.H.R.; Cheng, F. Senescence-specific change in ROS scavenging enzyme activities and regulation of various SOD isozymes to ROS levels in psf mutant rice leaves. Plant Physiol. Biochem. 2016, 109, 248-261. [CrossRef]

10. Borrás, L.; Maddonni, G.A.; Otegui, M.E. Leaf senescence in maize hybrids: Plant population, row spacing and kernel set effects. Field Crops Res. 2003, 82, 13-26. [CrossRef]

11. Zhao, H.; Dai, T.; Jing, Q.; Jiang, D.; Cao, W. Leaf senescence and grain filling affected by post-anthesis high temperatures in two different wheat cultivars. Plant Growth Regul. 2007, 51, 149-158. [CrossRef]

12. Luo, Z.; Guan, H.; Zhang, X.; Liu, N. Photosynthetic capacity of senescent leaves for a subtropical broadleaf deciduous tree species Liquidambar formosana Hance. Sci. Rep. 2017, 7, 1-9. [CrossRef] [PubMed]

13. Yamori, W.; Noguchi, K.O.; Hikosaka, K.; Terashima, I. Phenotypic plasticity in photosynthetic temperature acclimation among crop species with different cold tolerances. Plant Physiol. 2010, 152, 388-399. [CrossRef] [PubMed]

14. Wu, Y.X.; Von Tiedemann, A. Physiological effects of azoxystrobin and epoxiconazole on senescence and the oxidative status of wheat. Pestic. Biochem. Physiol. 2001, 71, 1-10. [CrossRef]

15. Dhindsa, R.S.; Plumb-dhindsa, P.; Thorpe, T.A. Leaf Senescence: Correlated with increased levels of membrane permeability and lipid peroxidation, and decreased levels of superoxide dismutase and catalase content. J. Exp. Bot. 1981, 32, 93-101. [CrossRef]

16. Wang, P.; Sun, X.; Li, C.; Wei, Z.; Liang, D.; Ma, F. Long-term exogenous application of melatonin delays drought-induced leaf senescence in apple. J. Pineal Res. 2013, 54, 292-302. [CrossRef]

17. Gill, S.S.; Khan, N.A.; Tuteja, N. Cadmium at high dose perturbs growth, photosynthesis and nitrogen metabolism while at low dose it up regulates sulfur assimilation and antioxidant machinery in garden cress (Lepidium sativum L.). Plant Sci. 2012, 182, 112-120. [CrossRef]

18. Jaleel, C.A.; Gopi, R.; Manivannan, P.; Gomathinayagam, M.; Murali, P.V.; Panneerselvam, R. Soil applied propiconazole alleviates the impact of salinity on Catharanthus roseus by improving antioxidant status. Pestic. Biochem. Physiol. 2008, 90, 135-139. [CrossRef] 
19. Waqas, M.; Yaning, C.; Iqbal, H.; Shareef, M.; Rehman, H.; Yang, Y. Paclobutrazol improves salt tolerance in quinoa: Beyond the stomatal and biochemical interventions. J. Agron. Crop Sci. 2017, 203, 315-322. [CrossRef]

20. Guoping, Z.; Jianxing, C.; Bull, D.A. The effects of timing of N application and plant growth regulators on morphogenesis and yield formation in wheat. Plant Growth Regul. 2001, 35, 239-245. [CrossRef]

21. Peng, D.; Chen, X.; Yin, Y.; Lu, K.; Yang, W.; Tang, Y.; Wang, Z. Lodging resistance of winter wheat (Triticum aestivum $\mathrm{L}$.): Lignin accumulation and its related enzymes activities due to the application of paclobutrazol or gibberellin acid. Field Crops Res. 2014, 157, 1-7. [CrossRef]

22. Wang, C.; Hu, D.; Liu, X.; She, H.; Ruan, R.; Yang, H.; Yi, Z.; Wu, D. Effects of uniconazole on the lignin metabolism and lodging resistance of culm in common buckwheat (Fagopyrum esculentum M.). Field Crops Res. 2015, 180, 46-53. [CrossRef]

23. Kuai, J.; Yang, Y.; Sun, Y.; Zhou, G.; Zuo, Q.; Wu, J.; Ling, X. Paclobutrazol increases canola seed yield by enhancing lodging and pod shatter resistance in Brassica napus L. Field Crops Res. 2015, 180, 10-20. [CrossRef]

24. Kamran, M.; Ahmad, I.; Wu, X.; Liu, T.; Ding, R.; Han, Q. Application of paclobutrazol: a strategy for inducing lodging resistance of wheat through mediation of plant height, stem physical strength, and lignin biosynthesis. Env. Sci. Pollut. Res. 2018, 25, 29366-29378. [CrossRef]

25. Kamran, M.; Cui, W.; Ahmad, I.; Meng, X.; Zhang, X.; Su, W.; Chen, J.; Ahmad, S.; Fahad, S.; Han, Q.; et al. Effect of paclobutrazol, a potential growth regulator on stalk mechanical strength, lignin accumulation and its relation with lodging resistance of maize. Plant Growth Regul. 2018, 84, 317-332. [CrossRef]

26. Jaleel, C.A.; Gopi, R.; Manivannan, P.; Panneerselvam, R. Responses of antioxidant defense system of Catharanthus roseus (L.) G. Don. to paclobutrazol treatment under salinity. Acta Physiol. Plant. 2007, 29, 205-209. [CrossRef]

27. Hajihashemi, S.; Kiarostami, K.; Saboora, A.; Enteshari, S. Exogenously applied paclobutrazol modulates growth in salt-stressed wheat plants. Plant Growth Regul. 2007, 53, 117-128. [CrossRef]

28. Arnon, D.I. Copper enzymes in isolated chloroplasts, polyphenol oxidase in Beta vulgaris L. Plant Physiol 1949, 24, 1-15. [CrossRef]

29. Giannopolitis, C.N.; Ries, S.K. Superoxide Dismutases: I. Occurrence in higher plants. Plant Physiol. 1977, 59, 309-314. [CrossRef]

30. Ekmekci, Y.; Terzioglu, S. Effects of oxidative stress induced by paraquat on wild and cultivated wheats. Pestic. Biochem. Physiol. 2005, 83, 69-81. [CrossRef]

31. Nakano, Y.; Asada, K. Hydrogen peroxide is scavenged by ascorbate-specific peroxidase in spinach chloroplasts. Plant Cell Physiol. 1981, 22, 867-880.

32. Heath, R.L.; Packer, L. Photoperoxidation in isolated chloroplasts. Arch. Biochem. Biophys. 1968, 125, $189-198$. [CrossRef]

33. Zhang, Y.J.; Zhang, X.; Chen, C.J.; Zhou, M.G.; Wang, H.C. Effects of fungicides JS399-19, azoxystrobin, tebuconazloe, and carbendazim on the physiological and biochemical indices and grain yield of winter wheat. Pestic. Biochem. Physiol. 2010, 98, 151-157. [CrossRef]

34. Borrás, L.; Slafer, G.A.; Otegui, M.E. Seed dry weight response to source-sink manipulations in wheat, maize and soybean: A quantitative reappraisal. F. Crop. Res. 2004, 86, 131-146. [CrossRef]

35. Fletcher, R.A.; Gilley, A.; Sankhla, N.; Davis, T.D. Triazoles as plant growth regulators and stress protectants. Hortic. Rev.. 2000, 24, 55-138.

36. Berova, M.; Zlatev, Z.; Stoeva, N. Effect of paclobutrazol on wheat seedlings under low temperature stress. Bulg. J. Plant Physiol. 2002, 28, 75-84.

37. Khalil, I.A.; Rahman, H. ur Effect of paclobutrazol on growth, chloroplast pigments and sterol biosynthesis of maize (Zea mays L.). Plant Sci. 1995, 105, 15-21. [CrossRef]

38. Tekalign, T. Growth, photosynthetic efficiency, rate of transpiration, lodging, and grain yield of Tef (Eragrostis Tef (Zucc.) Trotter ) as influenced by stage and rate of paclobutrazol application. East Afr. J. Sci. 2007, 1, 35-44. [CrossRef]

39. Gopi, R.; Jaleel, C.A.; Sairam, R.; Lakshmanan, G.M.A.; Gomathinayagam, M.; Panneerselvam, R. Differential effects of hexaconazole and paclobutrazol on biomass, electrolyte leakage, lipid peroxidation and antioxidant potential of Daucus carota L. Colloids Surf. B: Biointerfaces 2007, 60, 180-186. [CrossRef]

40. Rademacher, W. Growth Retardants: Effects on gibberellin biosynthesis and other metabolic pathways. Annu. Rev. Plant Physiol. Plant Mol. Biol 2000, 51, 501-531. [CrossRef] 
41. Xu, Z.; Huai, Z.; Pei, L.U.O.; Zheng, R.E.N. Effect of paclobutrazol on leaf senescence and yield of wheat. Acta Agric. Boreali-Sin. 2007, 22, 136-140.

42. Elanchezhian, R.; Haris, A.A.; Kumar, S.; Singh, S.S. Positive impact of paclobutrazol on gas exchange, chlorophyll fluorescence and yield parameters under submergence stress in rice. Indian J. Plant Physiol. 2015, 20, 111-115. [CrossRef]

43. Moradi, S.; Baninasab, B.; Gholami, M.; Ghobadi, C. Paclobutrazol application enhances antioxidant enzyme activities in pomegranate plants affected by cold stress. J. Hortic. Sci. Biotechnol. 2017, 92, 65-71. [CrossRef]

44. Bora, K.K.; Ganesh, R.; Mathur, S.R. Paclobutrazol delayed dark-induced senescence of mung bean leaves. Biol. (Bratisl). 2007, 62, 185-188. [CrossRef]

45. Wang, X.C.; Yang, W.Y.; Chen, G.; L I, Q.L.; Wang, X.-. Bin Effects of uniconazole on leaf senescence and yield of maize sprayed at late growth stage. J. Maize Sci. 2009, 17, 86-88.

46. Panneerselvam, R.; Muthukumarasamy, M.; Karikalan, L. Triadimefon enhances growth and net photosynthetic rate in $\mathrm{NaCl}$ stressed plants of Raphanus sativus L. Photosynthetica 1997, 34, 605-609. [CrossRef]

47. Gopi, R.; Sridharan, R.; Somasundaram, R.; Panneerselvam, R.; Lakshmanan, G.M.A.; Panneerselvam, R.; Lakshmanan, G.M.A.; Panneerselvam, R. Growth and photosynthetic characteristics as affected by triazoles in Amorphophallus campanulatus. Gen. Appl. Plant Physiol. 2005, 31, 171-180.

48. Abdul Jaleel, C.; Manivannan, P.; Sankar, B.; Kishorekumar, A.; Sankari, S.; Panneerselvam, R. Paclobutrazol enhances photosynthesis and ajmalicine production in Catharanthus roseus. Process Biochem. 2007, 42, 1566-1570. [CrossRef]

49. Yim, K.O.; Kwon, Y.W.; Bayer, D.E. Growth responses and allocation of assimilates of rice seedlings by paclobutrazol and gibberellin treatment. J. Plant Growth Regul. 1997, 16, 35-41. [CrossRef]

50. Navarro, A.; Sánchez-Blanco, M.J.; Bañon, S. Influence of paclobutrazol on water consumption and plant performance of Arbutus unedo seedlings. Sci. Hortic. 2007, 111, 133-139. [CrossRef]

51. Gilley, A.; Fletcher, R.A. Relative efficacy of paclobutrazol, propiconazole and tetraconazole as stress protectants in wheat seedlings. Plant Growth Regul. 1997, 21, 169-175. [CrossRef]

52. Zhong, X.; Che, X.; Zhang, Z.; Li, S.; Li, Q.; Li, Y.; Gao, H. Slower development of PSI activity limits photosynthesis during Euonymus japonicus leaf development. Plant Physiol. Biochem. 2019, 136, 13-21. [CrossRef]

53. Sheikh Mohammadi, M.H.; Etemadi, N.; Arab, M.M.; Aalifar, M.; Arab, M.; Pessarakli, M. Molecular and physiological responses of Iranian Perennial ryegrass as affected by Trinexapac ethyl, Paclobutrazol and Abscisic acid under drought stress. Plant Physiol. Biochem. 2017, 111, 129-143. [CrossRef] [PubMed]

54. Gill, S.S.; Tuteja, N. Reactive oxygen species and antioxidant machinery in abiotic stress tolerance in crop plants. Plant Physiol. Biochem. 2010, 48, 909-930. [CrossRef] [PubMed]

55. Jaleel, C.A.; Gopi, R.; Alagu Lakshmanan, G.M.; Panneerselvam, R. Triadimefon induced changes in the antioxidant metabolism and ajmalicine production in Catharanthus roseus (L.) G. Don. Plant Sci. 2006, 171. [CrossRef]

56. Mittler, R. Oxidative stress, antioxidants and stress tolerance. Trends Plant Sci. 2002, 7, 405-410. [CrossRef]

57. Noctor, G.; Mhamdi, A.; Chaouch, S.; Han, Y.; Neukermans, J.; Marquez-Garcia, B.; Queval, G.; Foyer, C.H. Glutathione in plants: An integrated overview. PlantCell Env.. 2012, 35, 454-484. [CrossRef] [PubMed]

58. Özmen, A.D.; Özdemir, F.; Türkan, I. Effects of paclobutrazol on response of two barley cultivars to salt stress. Biol. Plant. 2003, 46, 263-268. [CrossRef]

59. Hu, Y.; Yu, W.; Liu, T.; Shafi, M.; Song, L.; du, X.; Huang, X.; Yue, Y.; Wu, J. Effects of paclobutrazol on cultivars of Chinese bayberry (Myrica rubra) under salinity stress. Photosynthetica 2017, 55, 1-11. [CrossRef]

60. Akbari, G.A.; Hojati, M.; Modarres-Sanavy, S.A.M.; Ghanati, F. Exogenously applied hexaconazole ameliorates salinity stress by inducing an antioxidant defense system in Brassica napus L. plants. Pestic. Biochem. Physiol. 2011, 100, 244-250. [CrossRef]

61. Reddy, A.R.; Chaitanya, K.V.; Vivekanandan, M. Drought-induced responses of photosynthesis and antioxidant metabolism in higher plants. J. Plant Physiol. 2004, 161, 1189-1202. [CrossRef] [PubMed] 
62. Jaleel, C.A.; Gopi, R.; Manivannan, P.; Kishorekumar, A.; Gomathinayagam, M.; Panneerselvam, R. Changes in biochemical constituents and induction of early sprouting by triadimefon treatment in white yam (Dioscorea rotundata Poir.) tubers during storage. J. Zhejiang Univ. Sci. B 2007, 8, 283-288. [CrossRef] [PubMed]

63. Stern, R.A.; Raz, A.; Goldway, M. The growth retardant uniconazole is an effective blossom thinner for "Bing" cherry (Prunus avium). Acta Hortic. 2014, 1020, 513-520. [CrossRef]

(C) 2020 by the authors. Licensee MDPI, Basel, Switzerland. This article is an open access article distributed under the terms and conditions of the Creative Commons Attribution (CC BY) license (http://creativecommons.org/licenses/by/4.0/). 